Journal of Eukaryotic Microbiology 2019, vol 66

https://doi.org/10.1111/jeu.12744

\title{
Past President's Address: Protists of the Mesopelagic and a Bit on the Long Path to the Deep Sea ${ }^{1}$
}

John R. Dolana, Maria Ciobanua, and Laurent Coppola ${ }^{a}$

a. Laboratoire d'Océanographie de Villefranche-sur-Mer, Sorbonne Université, CNRS UMR 7093, Station Zoologique, 06230 Villefranche-sur-Mer, France

Correspondence

John R. Dolan, LOV, CNRS, Station Zoologique, 06230 Villefranche-sur-Mer, France

Telephone number: +33 4937638 22; FAX number +33 4937638 34; e-mail: dolan@obs-vlfr.fr

\begin{abstract}
The deep sea has long been a mysterious and attractive habitat for protistologists. However logistical difficulties severely limit sampling opportunities. Consequently, our knowledge of the protists in the deep sea, (arguably the largest habitat on earth), is relatively sparse. Here we present a unique time-series concerning 3 different protist taxa that share only the characteristics of being relatively large, robust to sampling, and easily identifiable to species level using light microscopy: tintinnid ciliates, phaeogromid cercozoans (e.g. Challengerids) and amphisolenid dinoflagellates. We sampled a near-shore deep water site in the N.W. Mediterranean Sea at 250 $m$ depth over a two-year period at approximately weekly intervals from January 2017 to December 2018. To our knowledge, no previous studies have employed sampling on a similar time scale. We found taxa that appear to be restricted to deep waters, distinct seasonal patterns of abundance in some taxa, and in others non-seasonal successional patterns. Based on data from sampling following a flash flood event, the Challengerid population appeared to respond positively to a pulse of terrigenous input. Some of the distinct mesopelagic tintinnid ciliates and amphisolinid dinoflagellates were also found in 2 samples from the North Atlantic mesopelagic gathered from near the Azores Islands in September 2018. We conclude that there are a variety of protist taxa endemic to the mesopelagic, that the populations are dynamic, and they may be widely distributed in the deep waters of the world ocean.
\end{abstract}

Keywords: Amphisolinidae; Deep-Sea; Phaeogromidae; Plankton; Time-series; Tintinnida

\footnotetext{
${ }^{1}$ Article based on a Past-President's address given at the annual meeting of the International Society of Protistologists held jointly with the Phycological Society of America at the University of British Columbia in Vancouver, July 29- August 2, 2018.
} 


\section{INTRODUCTION}

The search for protists in the deep sea has a long and distinguished history. Likely the first publication was Ehrenberg's "On microscopic life in the Ocean at the South Pole and at Considerable Depth" in which he described apparently living organisms from surface water (diatoms) in samples taken from 300 - 500 $m$ depth (Ehrenberg 1844). Interestingly, this finding of diatoms in good shape at great depths was re-discovered just a few years ago (Agusti et al. 2015). A few years after Ehrenberg's discoveries, Bailey reported "vast numbers of Globigerina" as well as diverse diatoms from material recovered from soundings in depths down to about $200 \mathrm{~m}$ on the North Atlantic coast of the U.S. (Bailey 1851). Ehrenberg later published descriptions of new forms, some now known as tintinnids and radiolarians, from bottom material brought up from deep waters in the North Atlantic (Ehrenberg 1854). Shortly after, Bailey described new "microscopic forms" from soundings taken at depths ranging from 1600 $2700 \mathrm{~m}$ in the North Pacific (Bailey 1856) and from across the Atlantic between the Canada coast and Ireland (Bailey 1857). From Mediterranean deep water mud samples, Ehrenberg described more new forms (Ehrenberg 1858). South Pacific deep water bottom samples were investigated by Ehrenberg (1861) and Harting (1863). Over about 20 years, protists were catalogued from a very wide range of deep sea sites.

Not long after the early protistological studies of Ehrenberg, Bailey and Harting was the Challenger Expedition (1872-1876). It famously opened the era of modern oceanography. Haeckel spent 10 years working on the deep water samples of the Challenger Expedition to produce his iconic and massive monographs of the Radiolaria (Haeckel 1887). The reports of diverse organisms found in the deep water trawls of the Challenger Expedition clearly established the suspected existence of a benthic fauna endemic to the deep sea. However, the existence of pelagic taxa (protist and multicellular), endemic to deep waters remained a debated matter well into the 20th century. Haeckel believed that there were radiolarians specific to certain deep sea depth strata but acknowledged that in the absence of closing plankton net samples (which did not exist at the time of the Challanger) the question of a deep sea pelagic radiolarian fauna was an open question (Haeckel, 1887, pg. cliii). The strongly opposing view was the school of Louis Agassiz, arguing that there was a vast life-less "azoic zone" between the surface waters and the deep-sea benthos as the devices he used failed to bring much up from deep water. Carl Chun and Karl Brandt championed the existence of a diverse and unique deep sea fauna, including protists (e.g., Fowler 1898). The arguments of Agassiz that alleged deep water forms were simply contaminants from surface waters were finally put to rest with the development of oceanographic devices allowing sampling at discrete depths with certainty of no contamination from surface waters (Mills 1980). Those first devices used were closing plankton nets and they were extensively employed during the Valdivia deep sea expedition 1898-1899 (Chun 1903) vindicating Haeckel's 1887 opinion. Chun's popular account of the expedition, "From the Depths of the Sea" (Chun 1903) included not only illustrations of deep sea fish but radiolarians as well (Fig. 1). 


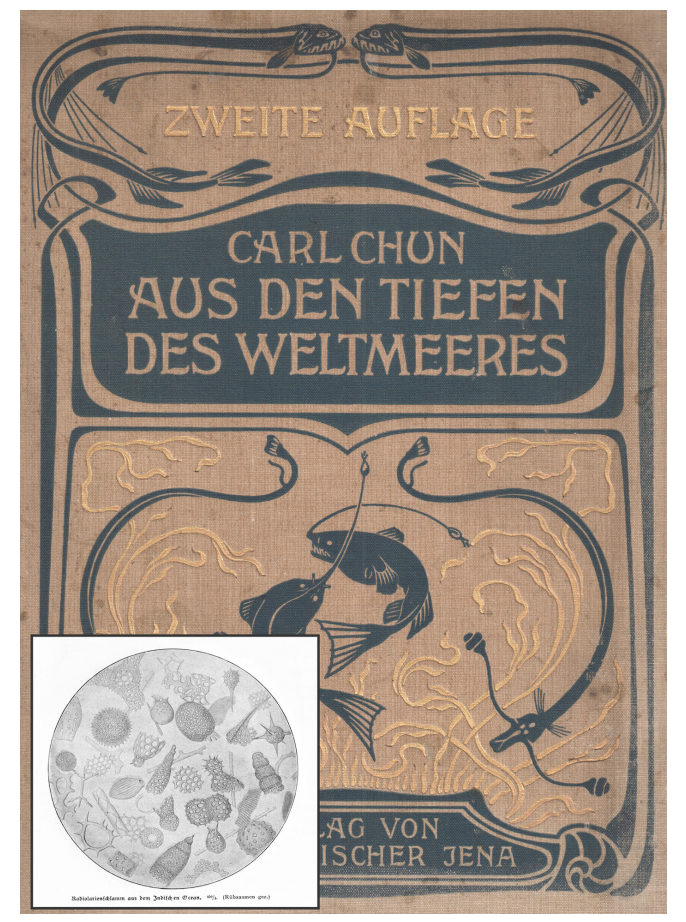

Fig. 1. The cover of the 1903 edition of Carl Chun's popular account of the Valdivia Expedition 1898-1899 "Aus den Tiefen des Weltmeeres" (From the Depths of the Ocean). Inset shows the illustration of radiolairians from the Indian Ocean on page 314.

The proposition that there are several vertical faunal zones in the sea, (from the surface down to abyssal depths of 1000-5000m), was first based on the distributions of radiolarians by Haecker (Russell 1927). Previous schemes simply divided the ocean into an illuminated surface layer, a twilight layer and the dark depths (e.g. Haeckel 1887; Lobianco 1903). Haecker (1908), based on collections made during the Valdivia expedition, defined several oceanic depth strata as Collodarian ("Collidenschicht" 0-50 m), Challengerid ("Challengeridentschicht" 50-400 m), etc. Now it is generally recognized that there are planktonic protists that are found in more or less specific depth strata in deep marine waters. This has been especially well documented in radiolaria (e.g., Boltovskoy 2017) as well as foraminifera (Rebotim et al. 2017 and references therein). Molecular studies have shown in at least one species of foraminifera, genetically distinct, 'cryptic species', inhabit different strata of deep waters (Weiner et al. 2012).

Outside the world of protistology, currently there is growing interest in the general ecology of the mesopelagic zone, the depth strata between 200 and $1000 \mathrm{~m}$ separating the illuminated water of the photic zone wherein photosynthesis occurs, and the completely dark, cold, and immense bathypelagic realm. Firstly, this reflects renewed interest in the "biological carbon pump" (the transit to, and long-term sequestration of organic carbon in, the bathypelagic) and more specifically, how the "pump" may be altered by climate change (e.g., Honjo et al. 2014; Boyd et al. 2017). Secondly, there is the overt recognition that our knowledge of the ecology of mesopelagic realm is actually sketchy (Costello \& Breyer 2017; St John et al. 2016). Questions raised decades ago concerning 
exactly how the mesopelagic food web is fueled (e.g., Marshall 1979; Kimor 2002) remain unanswered today. For example, measures of the flux of particulate carbon into the mesopelagic appear to be largely insufficient to meet estimates of respiratory energy demands of mesopelagic organisms (Burd et al. 2010; Robinson et al. 2010). Large uncertainty exists even with regard to the biomasses in the mesopelagic. New estimates of the biomass of myctophids, the small mesopelagic fish, the most numerous vertebrates on the planet, are an order of magnitude higher than previous estimates (Irigoien et al. 2014).

In recent years the protist fauna of the mesopelagic has not been neglected by protistologists (e.g., Edgcomb 2016). A few studies have even provided data on specific species of nanoflagellates (Arndt et al. 2003), radiolarians (Ikenoue et al. 2015); tintinnids (Krsinic \& Grbec 2006), and rates of bactivory (Pachiadaki et al. 2016) in the mesopelagic. However, for the most part, studies have generated data of two basic types. The first basic type is cell count data of large aggregate heterogeneous groups of diverse ecologies or phylogenetic affinities (i.e., "nano-sized flagellates", "ciliates", "dinoflagellates", "sarcodines"). The second type is rRNA sequence occurrence data, with the vast majority of sequences assigned to high-level taxa as many taxa are not wellrepresented in sequence databases.

Abundances (cell counts) of aggregate groups have been reported for a very wide range of localities. From across the world ocean between $30^{\circ} \mathrm{N}$ and $30^{\circ} \mathrm{S}$ from the Malaspina program (Pernice et al. 2015), to the subarctic Pacific (Fukada et al. 2007), the North West Pacific (Yamaguchi et al. 2002; 2004), the Tropical N Pacific to Arctic (Sohrin et al. 2010), the subtropical \& tropical Atlantic (Morgan-Smith et al. 2011), sites around the Canary Islands (Boras et al. 2010), the Tropical \& South Atlantic (Rocke et al. 2015), the Eastern and Western Mediterranean Sea (Rocke et al. 2015; Tanaka \& Rassoulzadegan 2002), and the Ross Sea in Antarctica (Safi et al. 2012).

Genetic surveys have also included a variety of mesopelagic sites ranging from the pioneering work of Lopez-Garcia et al (2001) in Antarctic waters, the Antarctic Ross Sea (Zoccarato et al. 2016) to the Sargasso Sea (Not et al. 2007), the North Atlantic (Grattepanche et al. 2016), the Eastern Tropical Pacific (Duret et al. 2015), Norwegian Sea deep water coral reefs (Jensen et al. 2012), submarine canyons of the N. W. Mediterranean Sea (Celussi et al. 2018), the South China Sea (Xu et al. 2017), and the West Pacific (Zhao et al. 2017). Taken as a whole, the studies, whether reporting on count or sequence data, suggest a very large variability in mesopelagic protist communities across various systems with reported concentrations varying by over an order of magnitude. Differences in general patterns such as changes in diversity with depth have been reported (Grattepanche et al. 2016). Notably, all of these studies are 'snapshots' sampling a given site a single time.

Time-series studies have long been acknowledged as invaluable in plankton studies as evidenced by the remarks of Ernst Haeckel (1891):

"To obtain a complete and more certain survey of the temporary variations of plankton composition requires an unbroken series of observations, carried on at one and the same place at least for the space of a full year-still better for several successive years-to obtain from the yearly and monthly oscillations a general average. 


\section{[...] As there are good and bad wine and fruit years, so there are rich and barren plankton years".}

To our knowledge, only a few studies have examined temporal variability in mesopelagic protists. Sequence-based studies employing sampling from monthly to quarterly intervals have been conducted in the San Pedro Channel of the California coast (Countway et al. 2010; Kim et al. 2014; Hu et al. 2016) and in the Canadian Arctic on several dates in different seasons (Terrado et al. 2009). The Arctic study found large seasonal differences in the composition of the mesopelagic protist assemblage. In contrast, the three San Pedro Channel studies all reported that variability was minimal in deep water communities $(150,500 \mathrm{~m}$ depth) compared to the surface water communities which showed large seasonal changes. A study by Gowing et al. of mesopelagic protists in the Arabian Sea, based on microscopic examination of material, found relatively small differences in the abundance and biomass in different monsoonal seasons (Gowing et al. 2003). These time-series studies present then conflicting views of mesopelagic protist communities as either seasonally variable or fairly invariant.

In a previous paper, our "exploratory study" (Dolan et al. 2017), we presented data showing remarkable changes in particular groups of protists related to seasonal changes in the structure of the water column in a near-shore deep water site in the N.W. Mediterranean Sea. We sampled at weekly intervals from early January 2017 to early June 2017 in both surface and deep waters. We focused on 3 groups in which species identification is relatively easy using light microscopy: tintinnid ciliates, phaeogromid cercozoans (Challengerids), and amphisolenid dinoflagellates. These protists of the microzooplankton are all not only relatively large, but also occur in very low concentrations, compared to those of nano and pico-plankton typically targeted in sequence-based studies.

We found that the mesopelagic tintinnid assemblage was composed of species found in the surface layer as well species apparently restricted to the mesopelagic. The deep-water species were a minor component of the assemblage during the winter mixing of the water column but dominated the assemblage when the water column stratification separates the surface and mesopelagic strata. The phaeogromids, nearly absent from surface waters, reacted negatively to winter water column mixing, declining to very low concentrations. We found a shift in the species composition of the amphisolinid dinoflagellates from dominance by species of Amphisolenia in the winter to dominance by Triplosolenia with water column stratification.

Our preliminary study showed then the existence of a temporally variable deep-water protist fauna. Consequently, we continued sampling and here report on data collected over 24 months, from early January 2017 to late December 2018, representing 85 sampling dates (the previous report was based 20 dates). Our goals were 1) to confirm apparent seasonal changes in composition reported in our preliminary study, 2) to obtain a more complete catalogue of the mesopelagic forms, and 3) to assess both the seasonality of species compositions as well as the inter-annual variability of mesopelagic assemblages. We also present data on mesopelagic protists from 2 sites near the Azores Islands (North Atlantic) that allow a preliminary comparison of protist assemblages from distant sites to evaluate the hypothesis that deep water taxa we encountered may have wide geographic ranges. 


\section{MATERIALS AND METHODS}

Details of our sampling protocol, sample processing and analysis, as well as data analyses are given in Dolan et al. (2017). Here we will but briefly summarize the method and materials previously described. Our study site is "Point C", a deep water standard sampling site of the French SOMLIT monitoring program ("Service d'Observation en Milieu LITtoral", SOMLIT/ILICO, the French Coastal Monitoring Network). The site is located about $1 \mathrm{~km}$ off the Cap de Nice $\left(\left(43^{\circ} 51^{\prime} 00^{\prime \prime} \mathrm{N}, 07^{\circ} 19^{\prime} 00^{\prime} \mathrm{E}\right)\right.$, near the entrance to the Bay of Villefranche (NW Mediterranean Sea). The SOMLIT program includes weekly water column profiles of salinity, temperature and oxygen down to depth of $300 \mathrm{~m}$ at the sampling site obtaining using a CTD probe. Data from the CTD profiles were used to characterize the water column at the sampling site in terms of water column stratification to distinguish periods of mixis from stratification, as detailed in Dolan et al. 2017. Briefly, a stratification index was calculated based on the difference in potential density between $10 \mathrm{~m}$ and $300 \mathrm{~m}$ following Behrenfeld et al. (2006), Dave and Lozier (2010), and Lozier et al. (2011); if the difference is $<0.125 \mathrm{kgm}^{3}$, the upper $300 \mathrm{~m}$ can be considered as non-stratified or mixed (de Boyer Montégut et al., 2004).

Our weekly sampling was conducted on the same or following day as the SOMILT program. Over the two-year period, we sampled 85 times with missing dates due to bad weather or unavailability of the boat due mechanical problems or maintenance. We obtained water samples using a $30 \mathrm{~L}$ Niskin bottle. The Niskin bottle was gently emptied, by prying open the lower cap, into a $20 \mu \mathrm{m}$ mesh plankton net suspended in a 30 L bucket. For the mesopelagic depth $(250$ $\mathrm{m}), 8$ bottle casts totaling $240 \mathrm{~L}$ were emptied into the plankton net. The net cod end material was fixed immediately with Lugol's ( $2 \%$ final concentration). The net was then thoroughly rinsed, to avoid sample contamination before sampling the surface layer at $30 \mathrm{~m}$ depth. In the lab, concentrated material from the plankton net samples of water from $250 \mathrm{~m}$ depth was examined in aliquots of 1 $3 \mathrm{ml}$ using an inverted microscope until material from an initial volume of approximately $100 \mathrm{~L}$ was analyzed. Similarly, material from about 20 liters initial volume from samples taken from $30 \mathrm{~m}$ depth was also examined. However, in this report we report only data from the $250 \mathrm{~m}$ sampling. The material from 30 $m$ depth sampling was used only to establish co-occurrence in surface layer or restriction to deep water.

We distinguished tintinnid taxa as either endemic to the mesopelagic "deep water" or in contrast forms primarily found in the surface mixed layer "surf" but occur also in deep waters. The assignation of tintinnid taxa broadly followed the criteria given in Dolan et al. (2017). Briefly, deep water species fulfilled 3 conditions: 1) found in deep water samples, 2) not found in surface samples on more than 2 dates, and 3) if found in surface water sample concentrations were trace (i.e., 1 cell). The contrasting species group, those from the surface mixed layer ("surf") found in deep waters, were forms fulfilling 2 conditions: 1) found in higher concentrations in surface compared to deep water samples, and 2) occurred more often in surface water samples than in deep water samples. Amphisolenid dinoflagellates and phaeogromid cercozoans were rarely found in surface waters thus there were no apparent surface layer species. 
Oligotrich ciliates larger than $20 \mu \mathrm{m}$ in longest dimension were also enumerated. Oligotrichs smaller than $20 \mu \mathrm{m}$ were abundant and frequently encountered but not recorded as water samples were initially concentrated using a $20 \mu \mathrm{m}$ plankton net. Statistical analysis was restricted to simple t-tests and correlations.

We recognize that examination of material from larger volumes of water taken from $250 \mathrm{~m}$ compared to $30 \mathrm{~m}$ results in different detection limits. The possibility exists that mesopelagic forms are not completely absent from the surface mixed layer but were exceedingly rare in the surface mixed layer samples.

Material from 2 sites near the Azores Islands in the North Atlantic was also analyzed. Sampling was graciously done by Hartmut Arndt onboard the Meteor, cruise M150. Niskin bottle samples were obtained from $250 \mathrm{~m}$ depth, 100 - $120 \mathrm{~L}$ were filtered through a $10 \mu \mathrm{m}$ plankton net and the net cod end material fixed with Lugol's solution. One site was about $500 \mathrm{~m}$ total depth $\left(38^{\circ} 48^{\prime} 43^{\prime \prime} \mathrm{N}, 27^{\circ} 03^{\prime} 06^{\prime \prime} \mathrm{W}\right)$ sampled on Sept. 12,2018 , the other was $1000 \mathrm{~m}$ total depth (36 $\left.53^{\circ} 93^{\prime \prime} \mathrm{N}, 2^{\circ} 07^{\prime} 19^{\prime \prime} \mathrm{W}\right)$ and was sampled on Sept. 18, 2018. Concentrated material was examined as described above and all material of the samples was examined.

\section{RESULTS}

\section{Tintinnid Ciliates}

A total of 81 morphologically distinct forms, putative species, were found in deep water samples. Of the 81, those apparently not endemic to deep waters, i.e., the "surf" taxa found in greater concentrations and more frequently in the samples from 30 m depth, numbered 65. Thus, we found 16 "deep water" species, that is taxa found more often and in greater abundances in the samples from $250 \mathrm{~m}$ depth. Figure 1 shows the 16 tintinnid forms found to be "deep species". All have hyaline (as opposed to agglutinated) lorica. The 16 deep water forms were of two basic sizes in terms of lorica opening diameter, either small $(10-25 \mu \mathrm{m}$ diam.) or large ( $40-60 \mu \mathrm{m})$, rather than consisting of a continuous spectrum of morphologies.

Several of the taxa appear to be new, as the lorica morphologies do not conform to any known species. Of the 16 deep water species 6 can be termed 'common', found on at least $50 \%$ of the dates. These common forms (noted in the caption of Fig. 2) are a morphologically diverse set with lorica opening oral diameters ranging from about $10 \mu \mathrm{m}$ to about $40 \mu \mathrm{m}$. However, none of the relatively large species (Daturella striata, Parundella lohmanni, Parundella messinsis, Xystonellopsis spicata) were found on a majority of the dates sampled. The complete data set for the 83 dates of the concentrations estimated for all 85 species is provided in the Supplementary Data File. 


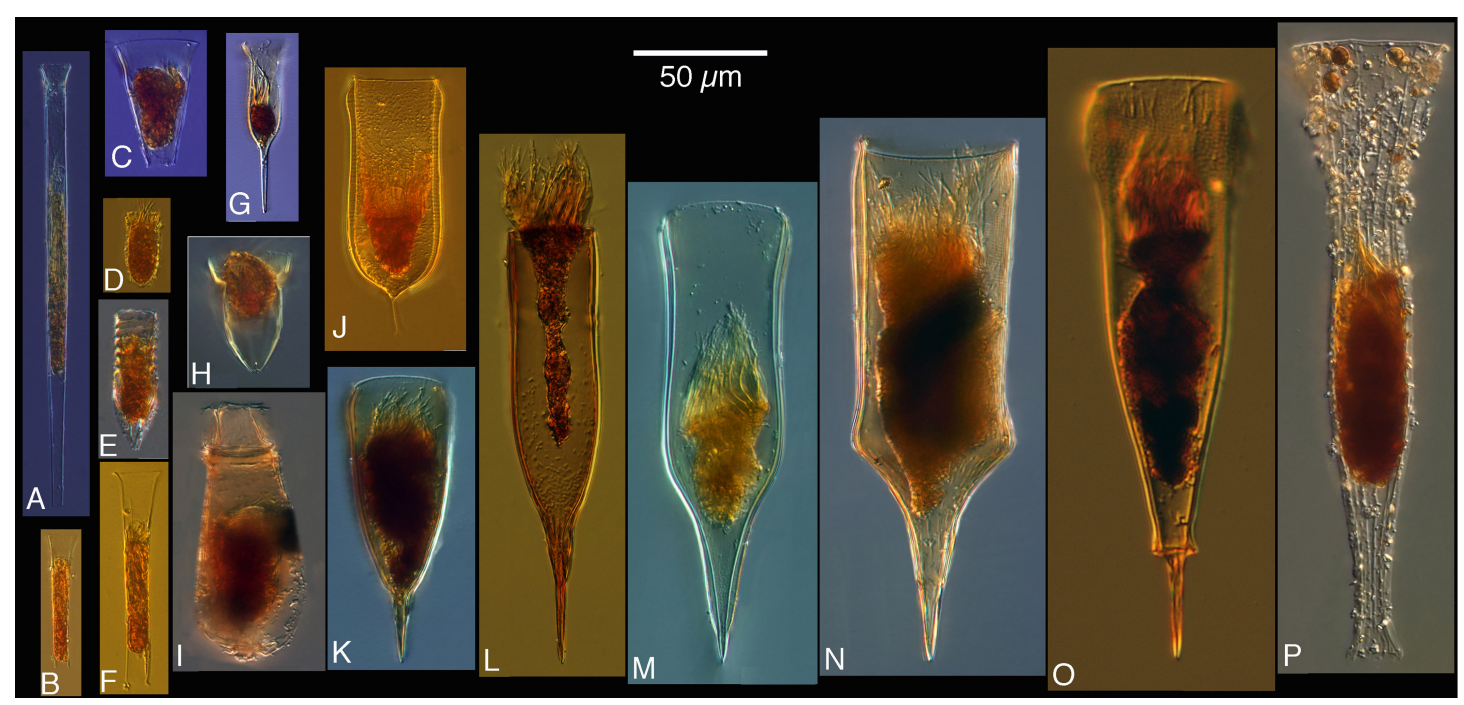

Fig. 2. Deep Sea Tintinnids. A. a new Salpingella sp., B. a new Eutintinnus spp., C. Eutintinnus haselae, D. a new Undella sp., E. a new 'ringed' Amphorellopsis sp., F. a new Eutintinnus sp., G. Albatrossiella agazzi, H. a new Ormosella sp., I. a new Brandtiella sp., J. Xystonellopsis aciculifera, K. Xystonellopsis scyphium, L. Parundella longa, M. Parundella lohmanni, N. Parundella messinensis, O. Xystonellopsis spicata, P. Daturella striata. Common species (found in $>50 \%$ of sampling dates were Albatrossiella agassizi (G), Amphorellopsis 'ringy' sp. (E), Xystonellopsis aciculifera (J), Ormosella sp. (H), Salpingella sp. (A), and Xystonellopsis scyphium (K). Note that we retain the original, incorrect spelling of E. hasalae (see Gomez 2007), as the appellation used most commonly in the literature.

Temporal changes in the total abundances of tintinnids (pooling deep species and forms found in surface waters) paralleled temporal changes in the concentrations of oligotrichs with peak abundances found during the period of winter mixis of the water column (Fig. 3). However most of variability in tintinnid abundances was due to large seasonal changes in the concentrations of "surf" forms, those found in surface waters with "deep species" concentrations varying relatively little (Fig. 4). This pattern is reflected in the coefficients of variation for the two groups (Table 1.). Simple correlation analysis indicated a close correspondence between the concentrations of "surf" tintinnids and oligotrichs rather than concentrations of deep water tintinnids (Fig. 5).

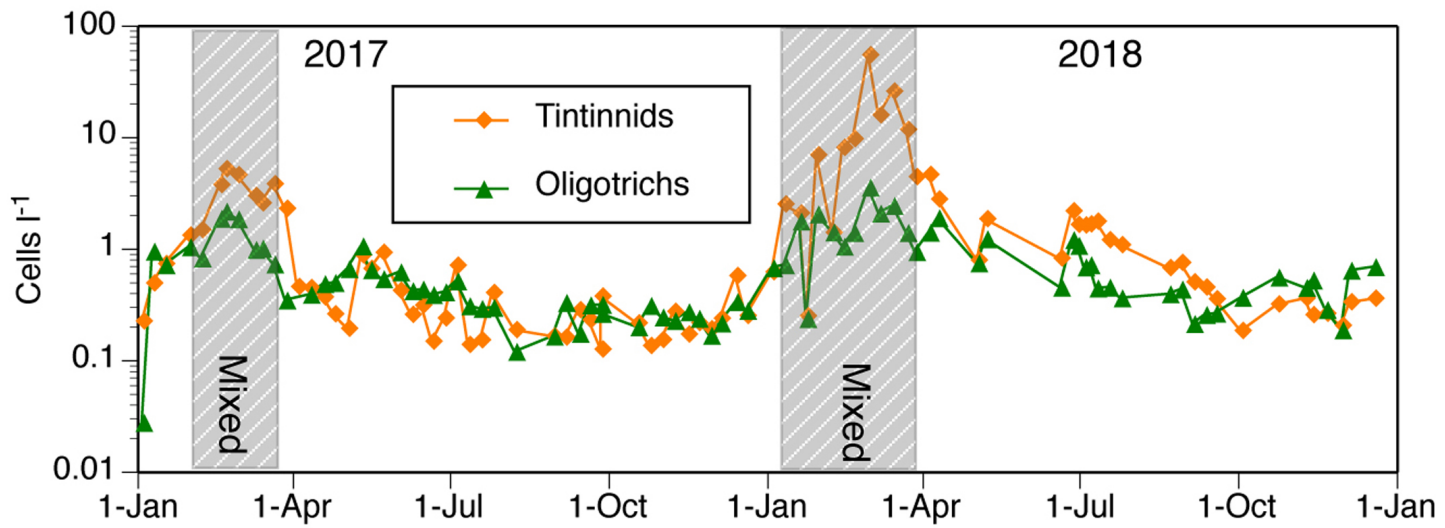

Fig. 3. Temporal changes in the abundance of tintinnids (total = "deep species" + "Surf", those found in higher concentrations and commonly in surface waters) and oligotrich ciliates. Grey striped boxes denote periods of mixed water column conditions (seawater density is homogenous throughout the water column). Note the similar temporal trends of total tintinnids and oligotrichs with marked peaks during the winter. 


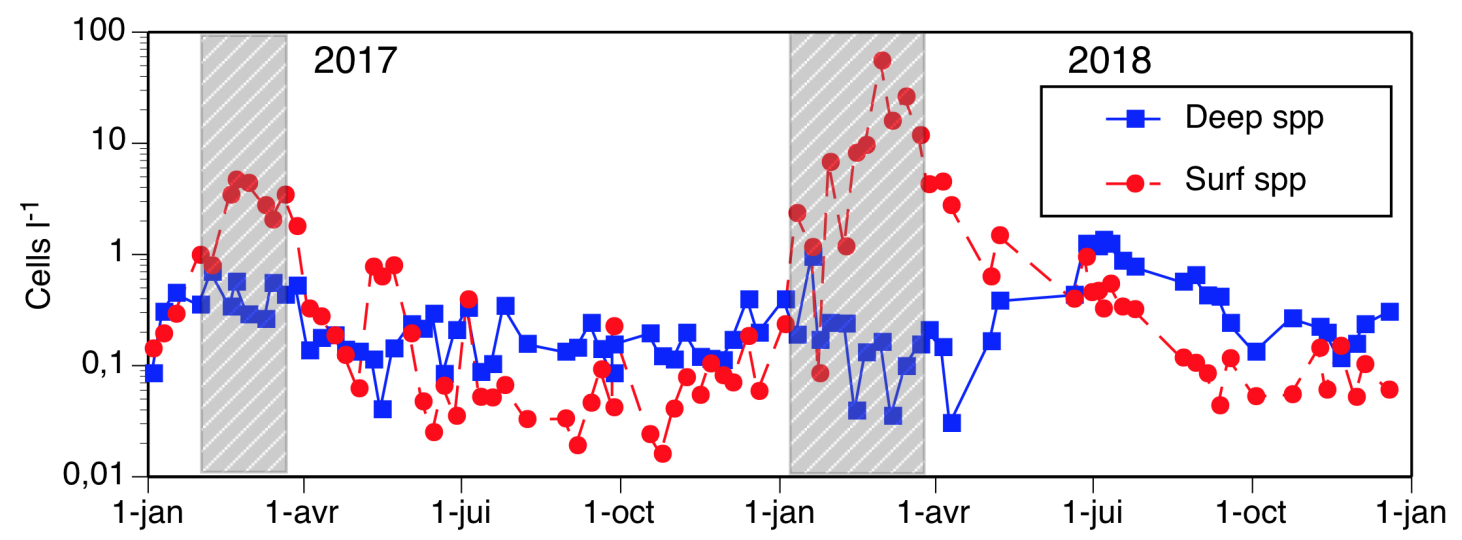

Fig. 4. Temporal changes in the abundance of tintinnids distinguishing "deep species" from "Surf", those tintinnid species also found in surface waters, and oligotrich ciliates. Grey striped boxes denote periods of mixed water column conditions (seawater density is homogenous throughout the water column). Note that "Surf spp" dominated the tintinnid assemblage during periods of water column mixing in both years but were otherwise usually a minority component of the tintinnid assemblage.

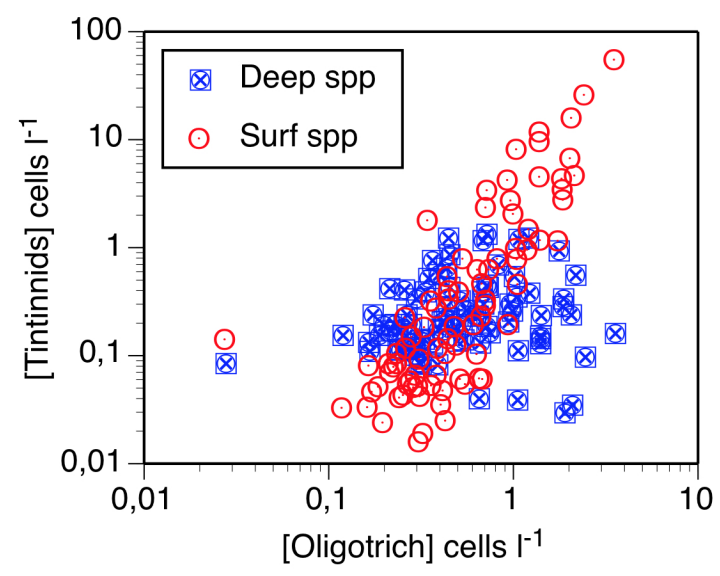

Fig. 5. Correlation of concentrations of oligotrich ciliates (cells $>20 \mu \mathrm{m}$ diameter) with concentrations of deep water species of tintinnids and concentrations of Surf species of tintinnids. Concentrations of oligotrichs were closely related to those of "Invasive" tintinnids ( $\mathrm{r}=$ $0.79, \mathrm{n}=84$ ) but not concentrations of "deep" tintinnids $(\mathrm{r}=0.03, \mathrm{n}=84)$.

The most commonly encountered deep sea tintinnids were forms with small lorica oral opening diameters: Salpingella sp. (Fig. 1 A.), the 'ringed' Amphorellopsis sp. (Fig. $1 \mathrm{E}$ ) and Albatrossiella agassizi (Fig. 1. G.). None of the three species showed any obvious seasonality. Throughout 2017 the 3 appeared to vary independently of one another but they did peak together in the summer of 2018. (see supplemental Fig. 1). Some deep water tintinnid species did show seasonal shifts in abundance coinciding with changes in the stratification of the water column. Xystonellopsis aciculifera and X. spicata showed contrasting patterns with $X$. spicata peaking during the winter periods of water column stratification and the relatively common $X$. aciculifera was not detected during those periods (Fig. 6). 

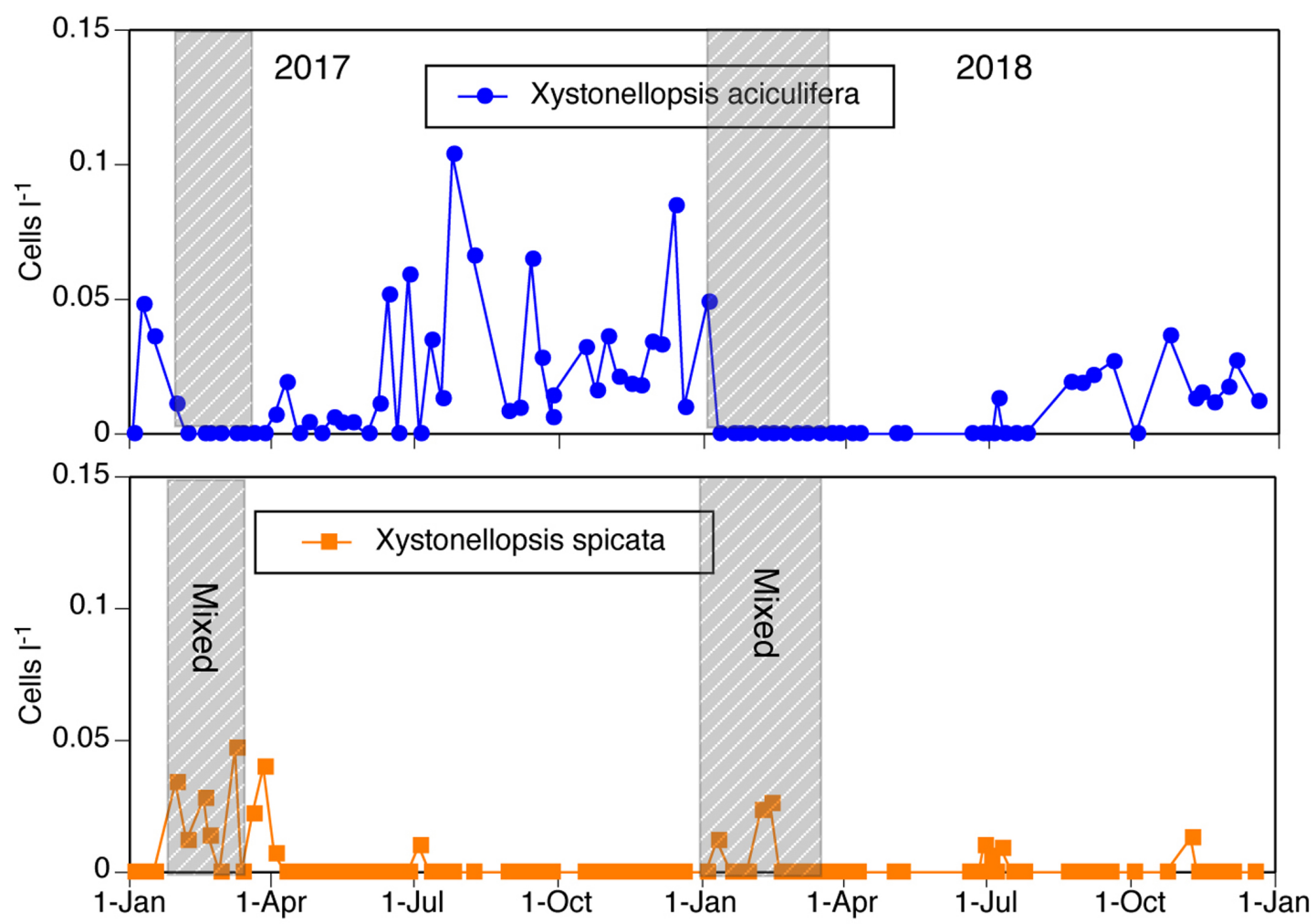

Fig. 6. Temporal variability, suggestive of seasonality, of the deep sea tintinnid species Xystonellopsis aciculifera and X. spicata. Periods of water column mixing, indicated by grey striped boxes, corresponded to the absence of $X$. aciculifera and the peak abundances of $X$. spicata.

Comparing 2017 and 2018, some differences are readily apparent. Average concentrations were higher and variability greater in 2018 compared to 2017. This applied to both both "Deep Sea" and "Surf" species. The Deep Sea

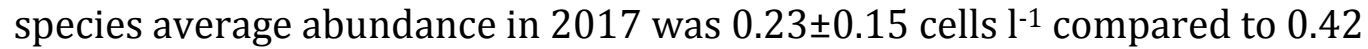
\pm 0.39 cells $^{-1}$ in 2018 . The "Surf" species average abundance was considerably higher in $2018,4.12 \pm 9.99$ cells l$^{-1}$ compared to $0.65 \pm 1.18$ cells $^{-1}$ in 2017 .

However, the trend did not apply to all species. Note that Figure 6 shows that both Xystonellopsis aciculifera and X. spicata were more abundant and occurred more often in 2017 compared to 2018.

A temporal rarefaction curve showed some expected and unexpected trends. Plotting cumulative number of species encountered as a function of cumulative number of samplings (Fig. 7) shows that most of the deep water species were encountered in the first samplings and only 1 'new' deep water species was added in 2018. The catalogue of "Surf" species, those usually found in the surface layer but encountered in the deep water, samples increased steadily and show no signs of reaching a plateau. 


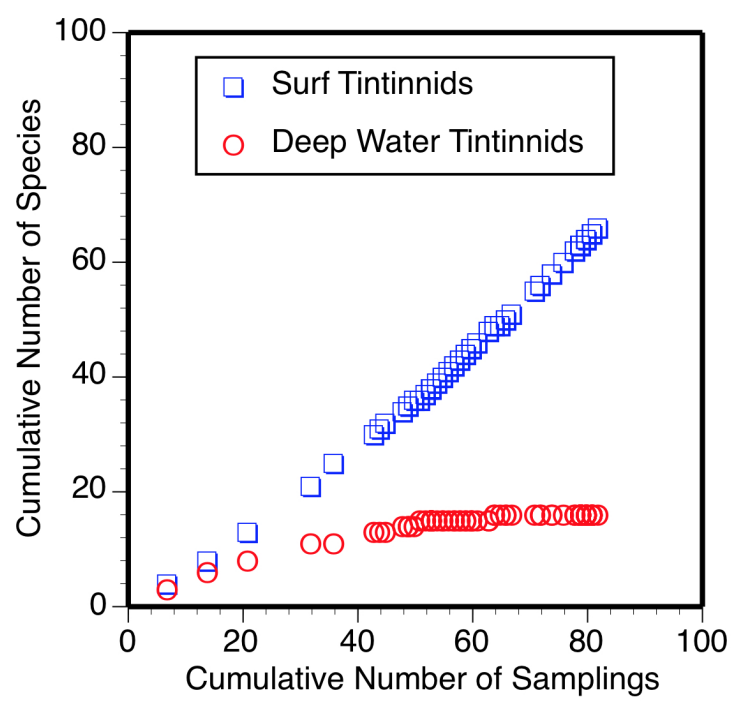

Fig. 7. The cumulative number of tintinnid species encountered as a function of the number of samplings (in chronological order from January 3, 2017 to December 18, 2018). Note that of the 16 species deep water tintinnid species found, most were found in the first few samplings. The majority of the 82 species encountered were "Surf", those found in higher concentrations and more often in surface waters. The plot suggests that the number of Surf species encountered will likely increase with further sampling effort, unlike the list of deep water forms.

\section{Phaeogromid Cercozoans}

We encountered 10 taxa of the genera Challengeranium, Challengeron, Challengeria, Euphysetta, Lirella, and Medusetta in samples from $250 \mathrm{~m}$ depth (see Supplementary Data File). The 7 most frequently encountered species, displaying a conspicuously wide range of morphologies are shown in Figure 8. Only 3 species could be termed 'common', found on over $50 \%$ of the dates, were Challengeranium diadon, Challengeron willemoesii and Challengeria xiphodon.

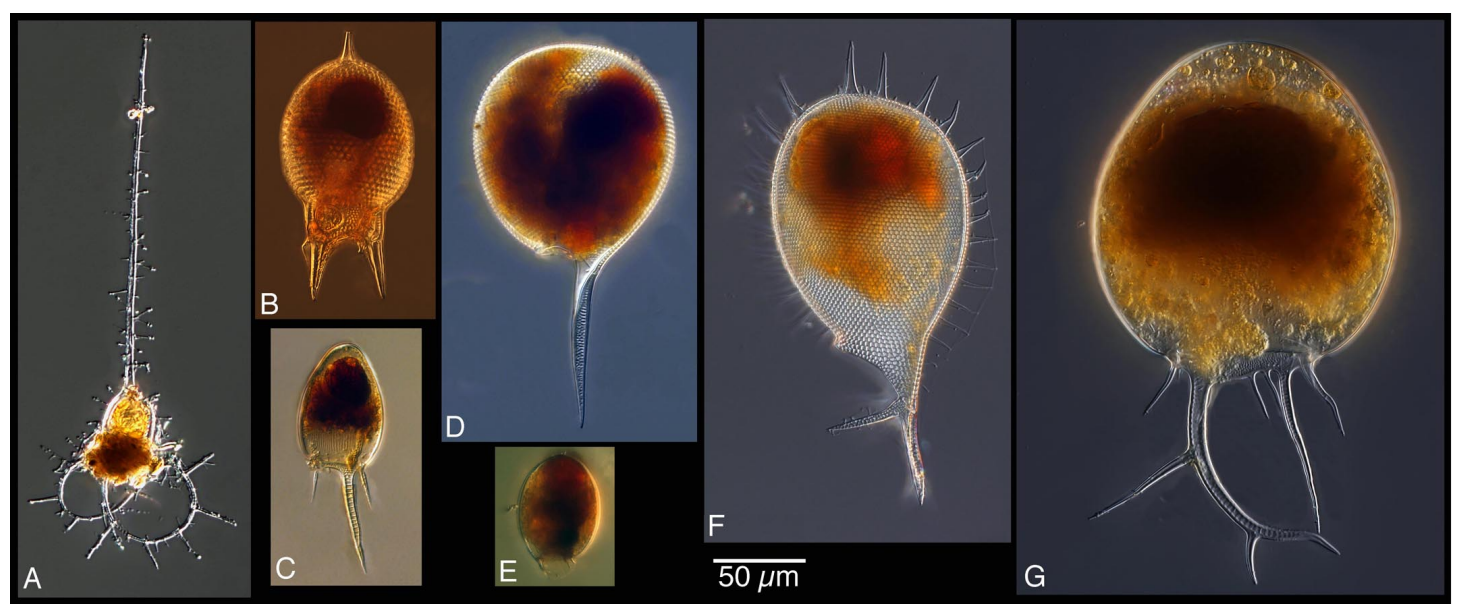

Fig. 8. Species of phaeogromid cercozoans found on at least $10 \%$ of the sampling dates. A. Medusetta parthenopaea, B. Challengeranium diadon, C. Euphysetta pusilla, D. Challengeria xiphodon, E. Lirella bullata, F. Challengeron willemoesii, G. Euphysetta lucani. Common species (found on $>50 \%$ of sampling dates): Challengeron diadon (B), Challengeron willemoesi (F) and Challengeria xiphodon (D). 
The three most common species all showed low abundances during the periods of water column mixing but differed with regard to their period of peak abundance (Fig. 9). Challengeranium diadon, the most abundant and frequently occurring phaeogromid, had peak abundance in early summer. The large Challengeron willemoesii was most abundant in late summer- early autumn and Challengeria xiphodon was most abundant in the spring. The distinct periods of peak abundance in the 2 most common forms, $C$. diadon and $C$. xiphodon resembled a successional pattern with $C$. xiphodon peaking shortly before $C$. diadon. Comparing 2017 and 2018, the average abundances of phaeogromids were nearly identical, unlike the tintinnids. Average abundance in 2017 was $0.074 \pm 0.050$ cells $l^{-1}$ compared to $0.065 \pm 0.49$ cells l-1 $^{-1}$ for 2018 .
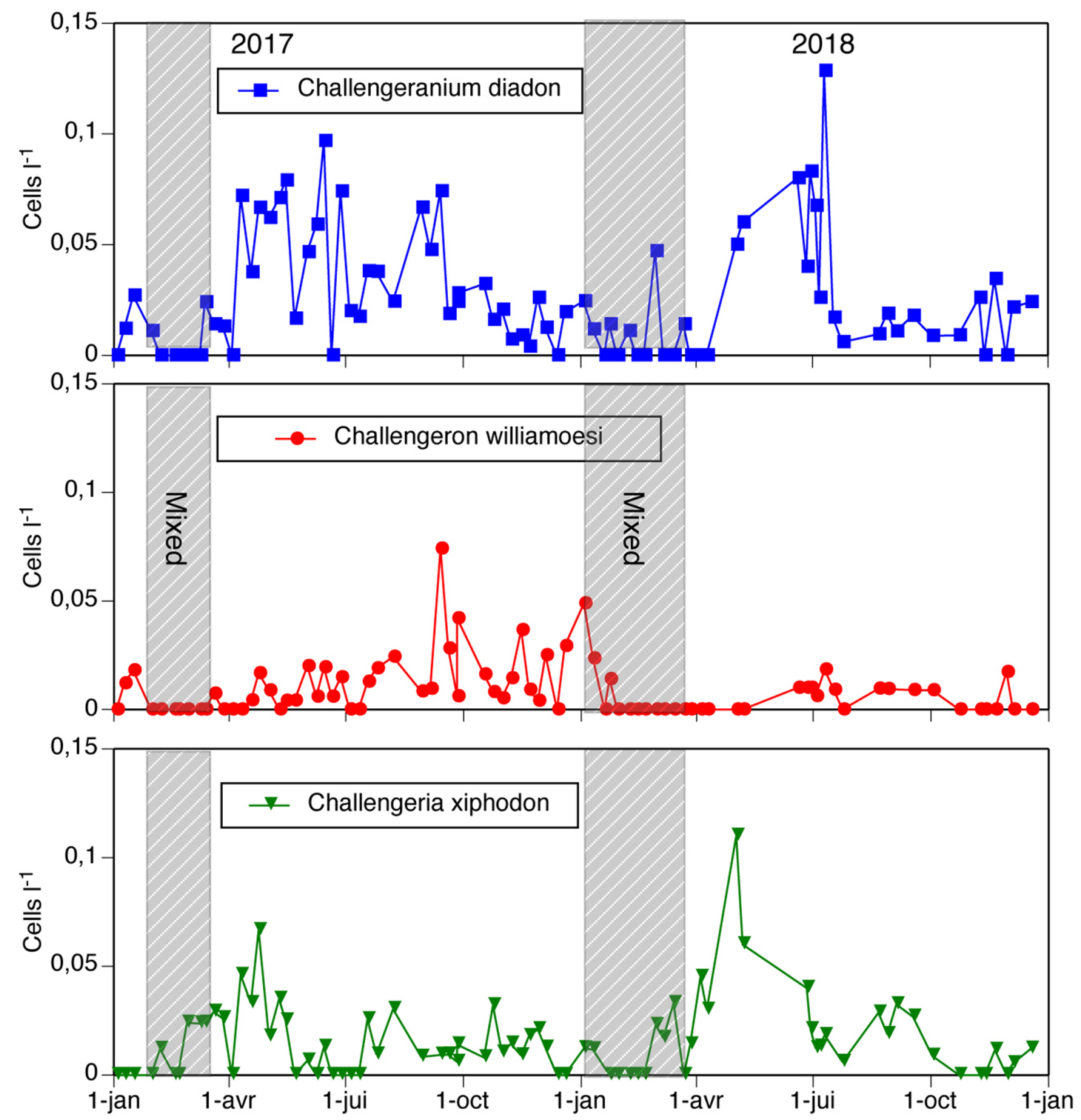

Fig. 9. Temporal variability of the 3 most commonly encountered phaeogromid species: Challengeranium diadon, Challengeron willamoesi, and Challengeria xiphodon. Periods of water column mixing, indicated by grey striped boxes, corresponded to the absence or low abundance of all three species. Note that the periods of maximal concentrations differed for the 3 species. $C$. diadon was most abundant in June-July of 2017 and 2018. C. williamoesi peaked in September in 2017 then in July and again in November of 2018. C. xiphodon peaked in May in both 2017 and 2018. 
A total of 7 amphisolenid taxa were encountered. The most frequently occurring species (56 of the 85 dates) was Triposolenia bicornis, the only Triposolenia species found. Amphisolenia was represented by 6 taxa with A. globifera occurring most often ( 54 of the 85 dates). The other Amphisolenia species ( $A$. bidentata, A. extensa, A. brevicaudata and A. truncata) were found on few dates (1-13). Very occasionally specimens in which the structure of the 'foot' were unclear were encountered and recorded as "Amphisolenia sp." in the supplementary data file. The 4 forms most commonly encountered are shown in Figure 10.

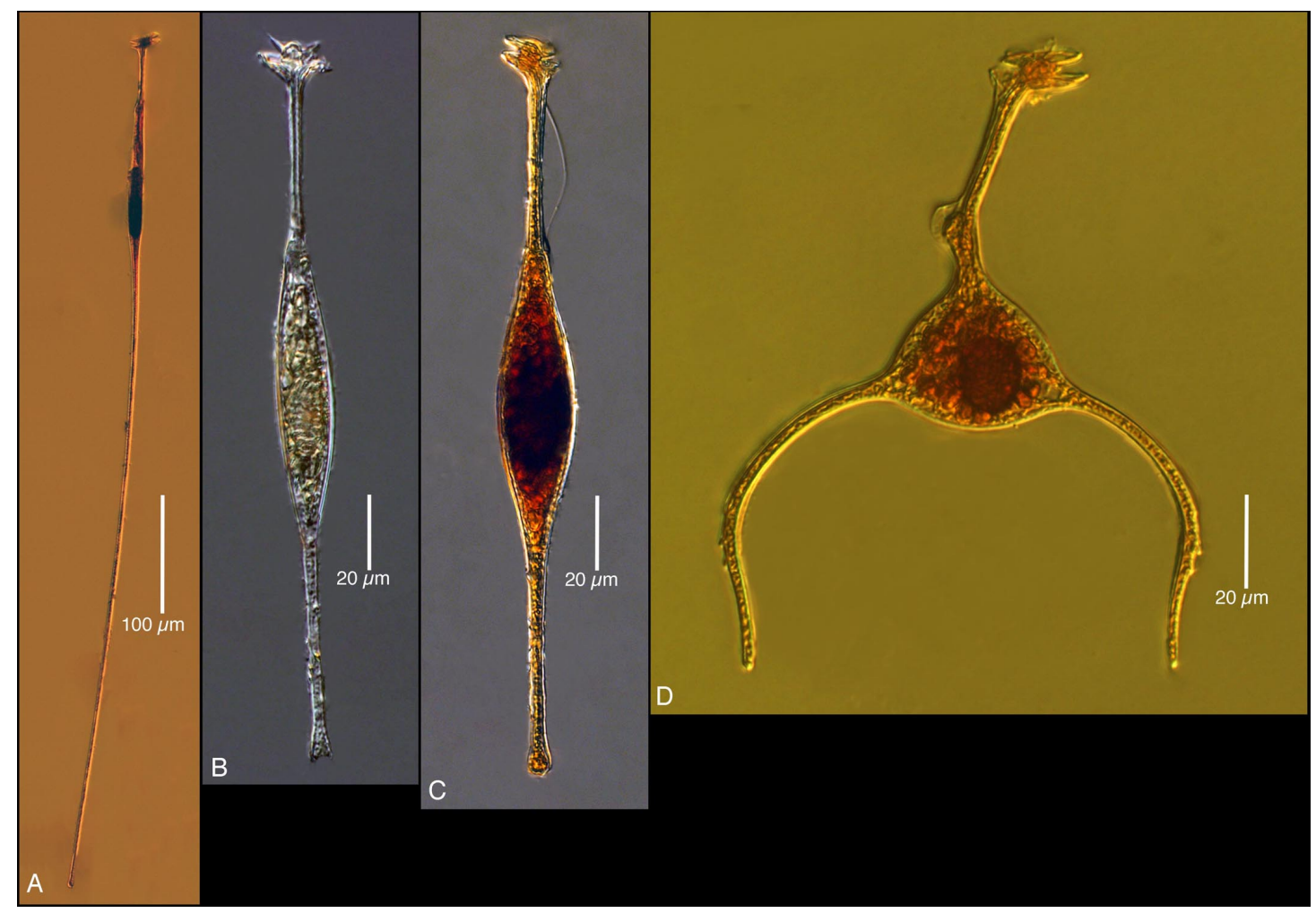

Fig. 10. Species of Amphisolinid dinoflagellates found on at least 8\% of the sampling dates. A. Amphisolenia extensa, B. Amphisolenia bidentata, C. Amphisolenia globulosa, D. Triposolenia bicornis. Only A. globulosa and T. bicornis were found on a majority of sampling dates.

Triposolenia and Amphisolenia spp. displayed distinct temporal patterns of abundance. (Figure 11) Triposolenia was nearly absent during periods of water column mixis and peak abundances were found in late summer. In contrast, Amphisolenia spp. were most abundant during the periods of water column mixing and found in lower concentrations than Triposolenia during summer months. The average abundance of amphisolenid dinoflagellates throughout 2017 was $0.06 \pm 0.04$ cellsl $^{-1}$, slightly lower than the $0.04 \pm 0.04$ cells $^{-}$ 1 for 2018. 

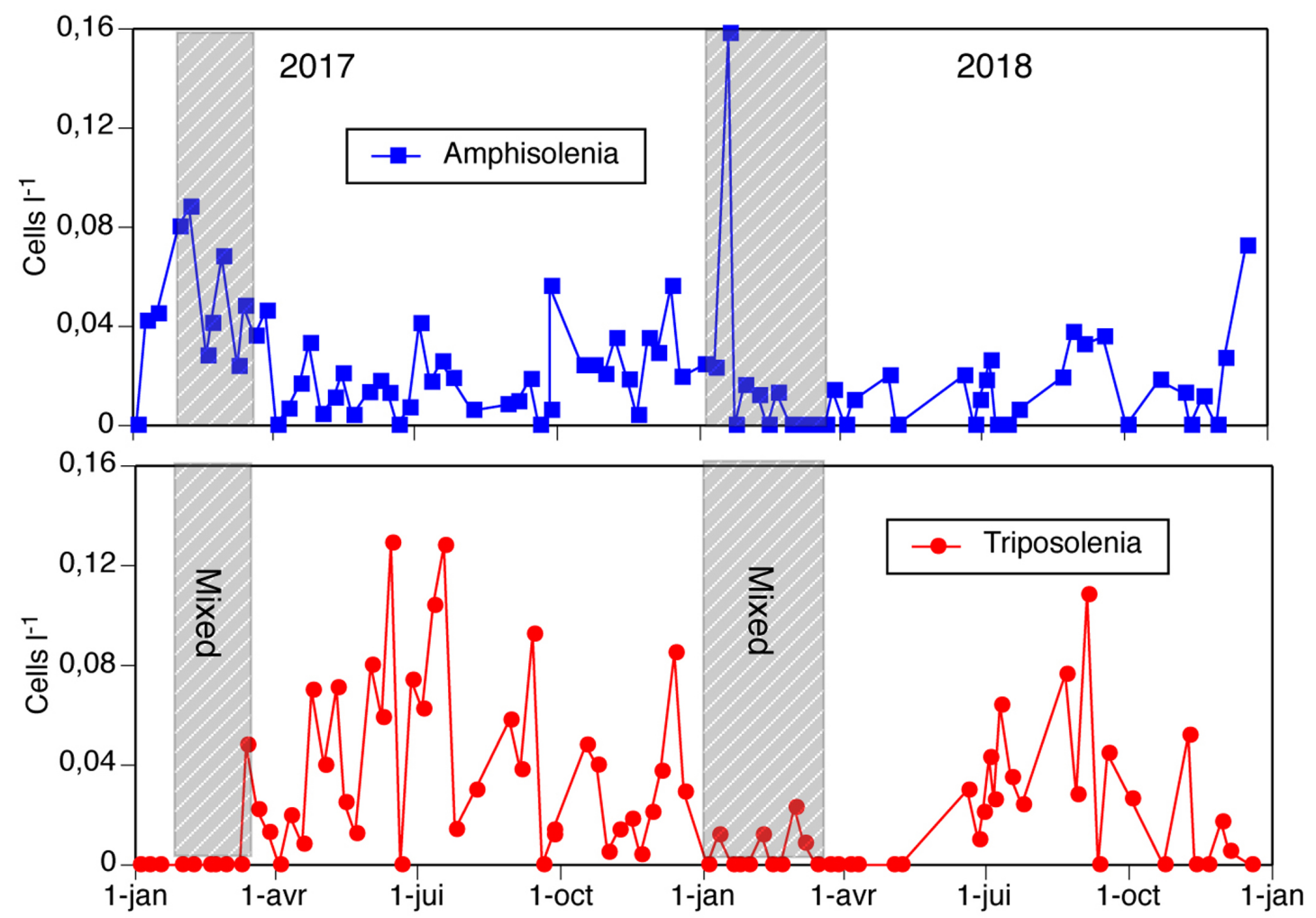

Fig. 11. Temporal variability, suggestive of seasonality, of species of Amphisolenia (all forms pooled) and Triposolenia bicornis. Periods of water column mixing, indicated by grey striped boxes, corresponded to the apparent absence of $T$. bicornis and the peak abundances of Amphisolenia spp.

\section{Observations Following a Flash Flood Type Event}

Samples taken on July 6, July 10, and July 17, 2018 permitted observation of the effects of an input of terrigenous matter into deep water. On July 5th 2018 in the early evening an intense, 30 minute, rainstorm occurred ending a period of several weeks without rain in the region. The rainfall was reported as $2 \mathrm{~cm}(=20$ 1 per $\mathrm{m}^{2}$ ) over the metropolitan region of approximately $100 \mathrm{~km}^{2}$. Sampling $16 \mathrm{~h}$ after the rain event on July 6th we observed a great deal of particulate matter on the sea surface. The quantity and qualities of the material floating at the surface we had not previously nor subsequently seen (see supplemental fig. 2). However, the sample from $250 \mathrm{~m}$ depth contained an average or unremarkable concentration of particulate matter (particles $\geq 20 \mu \mathrm{m}$ retained in the plankton net). In contrast, the sample collected 4 days later was heavily charged with particulate matter and the sample collected 11 days following the rain event showed a return to a 'normal' load of particulate matter (see Figure 12). 

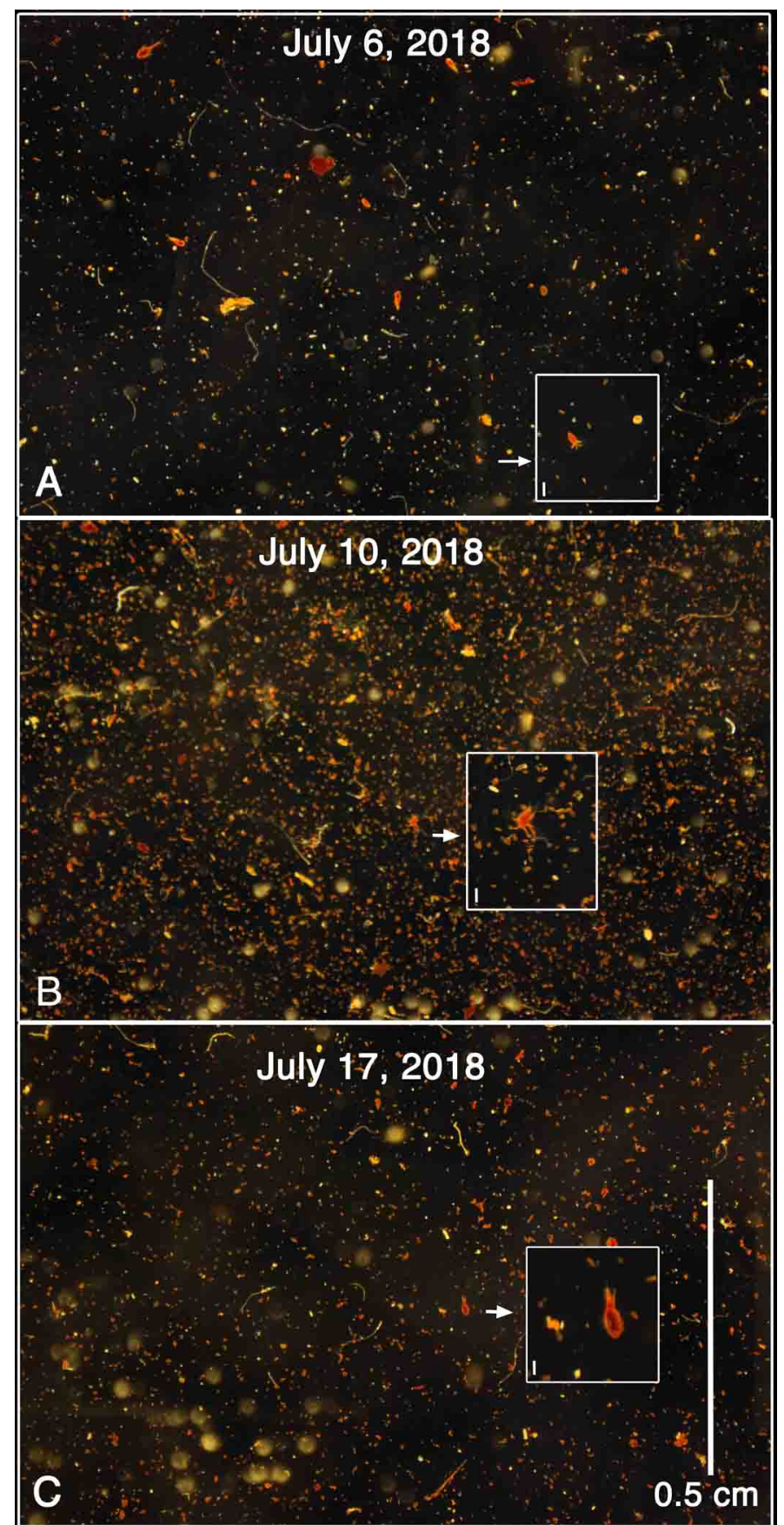

Fig. 12. Particulate matter (particles $\geq 20 \mu \mathrm{m}$ ) load in samples taken at $250 \mathrm{~m}$ depth 16 hours following a rainstorm (A- July 6, 2018), 5 days post-storm (B- July 10 2018) and 12 day poststorm (C- July 17 2018). Areas shown contain material from about $5 \mathrm{l}$ of water. Insets show magnified views to show particle sizes relative to copepod nauplii (A, B) or a copepodite (C). Inset scale bars $=100 \mu \mathrm{m}$.

The graphs showing temporal changes in organismal concentrations (Figs. $3,4,6,7,9,10,12$ ) show an apparent shift in the abundance of only one taxon on July 10th 2018, relative to the preceding (July 6th 2018) and following dates (July 17 2018). The phaeogromid Challengerium diodon showed an abrupt increase in abundance from about 0.03 cells l$^{-1}$ on July 6th to 0.13 cells $\mathrm{l}^{-1}$ of July 10 th and then a decline to 0.02 cells l$^{-1}$ on July 17 th (Fig. 9). The increase in abundance from July 6 th to July 10 th translates into a generation time of about 2 
days. Notably then only one taxon showed an apparent distinct change in abundance coinciding with the detection of large amounts of particulate matter, presumably input from the rainstorm.

\section{Azores Deep Water Samples}

We found both similarities and differences in the tintinnid, phaeogromid and amphisolinid faunas of the North Atlantic compared to the Mediterranean site. While the two samples yielded very different estimates of organismal concentrations (see supplemental data file), the average concentrations estimated from the Azores sample were very similar to those encountered at the Mediterranean site, excluding the periods of water column mixis. In the following description the organismal concentrations given represent an average of the 2 Azores samples compared to the average concentrations of the Mediterranean site during the stratified period. In the Azores, samples tintinnids were found in concentrations of about 0.2 cells $\mathrm{l}^{-1}$ compared an average of about 0.3 cells $^{-1}$ in the Mediterranean site. The phaeogromids were less abundant than the tintinnids, 0.07 cells $\mathrm{l}^{-1}$, similar to the concentrations found in the Mediterranean site, 0.08 cells $1-1$. The Amphisolinid dinoflagellates were more abundant in the Azores samples, 0.14 cells l-1 $^{-1}$ compared to 0.06 cells l-1 $^{-1}$ at the Mediterranean site.

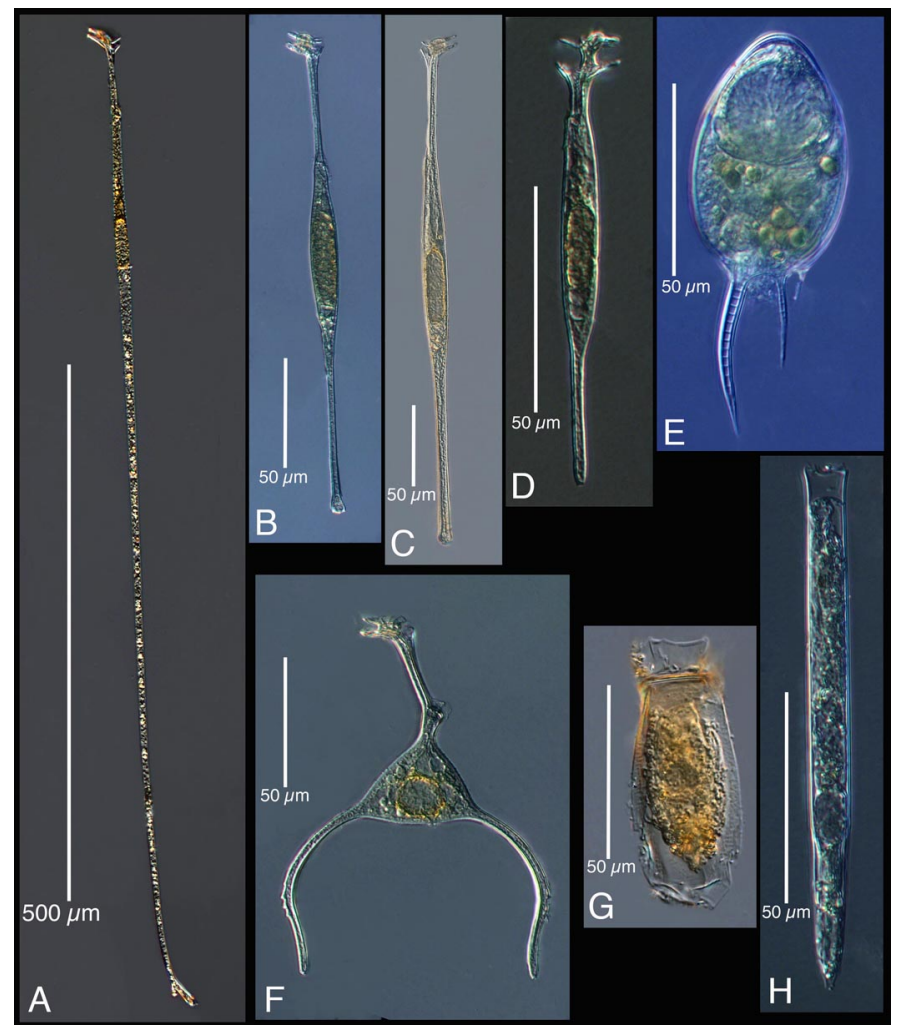

Fig. 13. Examples of forms found in the samples from $250 \mathrm{~m}$ depth at two sites in the North Atlantic Ocean near the Azores. Amphisolenid dinoflagellates included the large species $A$. astralagus (A), the moderately-sized A. bidentata (B) and A. globulosa (C) and the small $A$. lacintata (D) and Triposolenia bicornis (F). The most abundant phaeogromid was Euphysetta pusilla (E). The tintinnids were dominated by a small form of Salpingella $(\mathrm{H})$ differing from the small Mediterranean Salpingella (Fig. 1A) as the oral opening of the lorica lacks flared opening of the Mediterranean form. Also found were specimens closely resembling the Brandtiella sp (G) found in the Mediterranean samples (Fig. 2I). 
Similarities and differences were also found in the taxonomic composition of the assemblages in the Azores samples compared to the Mediterranean site. The most abundant tintinnid species in the Azores samples was a very thin form of Salpingella (Fig. 13H), similar to but not identical to, the thin Salpingella form dominant among the deep sea forms in the Mediterranean samples (Fig. 2A, Fig. 6). The second most common tintinnid form in the Azores samples was an undescribed Branditiella form (Fig. 13G) found also in the Mediterranean samples (Fig. 2I). In the Azores samples the composition of the Phaeogromid assemblage was similar to that found in the Mediterranean site but the relative importance of species differed. The phaeogromids were dominated by Euphysetta pusilla (Fig. 13E), also found in the Mediterranean site (Fig. 9C) but as a minor component, and the dominant phaeogromid form of the Mediterranean site, Challengerianum diadon (Fig. 8A, Fig. 9) while present, was a minor component of the assemblage in the Azores samples. The most common amphisolinid dinoflagellate was a small form, Amphisolenia lacintata (Fig. 13D). Nearly as abundant were two forms common in the Mediterrean site, $A$. bidentata (Fig. 10B) and A. globulosa (Fig. 10C). Also found in the Azores sample was Triposolenia bicornuta (Fig. 13F) a dominant form in the Mediterranean samples, and a large, apparently rarely seen, $A$. astragalus (Fig. 13A) resembling in it large size A. extensa found in the Mediterranean samples (Fig. 10A).

\section{DISCUSSION}

In our previous exploratory study (Dolan et al. 2017), we showed changes in the abundances of different groups of deep water protists related to seasonal changes in the structure of the water column at our site in the N.W.

Mediterranean Sea. The study concerned the period from early January 2017 to early June 2017. Having found organisms and patterns of interest, we continued our sampling and the data presented here are from sampling 85 dates over a 2year period. With the extended time series, we set out 1 ) to obtain a more complete catalogue of the mesopelagic forms, 2) to confirm apparent seasonal changes in composition reported in our preliminary study, and 3) to assess possible inter-annual variability of mesopelagic assemblages. In addition, sampling just after a flash flood event allowed evaluation of the response of the deep water protists to an apparent input of terrigenous matter. Material from a pair of deep water samples from a distant site, the North Atlantic near the Azores Islands, afforded a chance to determine if the forms found in the N.W.

Mediterranean Sea might be widely distributed.

With regard to the catalogue of mesoplelagic forms, our temporally extensive sampling uncovered only a few confirmed deep water forms (i.e., not found in surface layer samples) that were not seen in the first 5 months of sampling. Continued sampling for another 18 months recovered but a single additional deep water tintinnid ciliate species, the Brandtiella sp.. The vast majority of additional tintinnid species encountered were forms primarily inhabiting surface waters. Among the phaeogromid cercozoans, only two forms not detected in the first 5 months were found: Challengeron channeri and Lirella bullata. For the amphisolenid dinoflagellate, a single species was added to the catalogue: Amphisolenia brevicauda (for details see supplementary data file). These findings suggest that the deep water forms are stable sets, composed of 
relatively few species, with little inter-annual variation in species composition at least at the site sampled.

The samples provided by Hartmut Arndt of deep water sites near the Azores Islands allowed an opportunity, albeit quite limited, to compare the Mediterranean assemblages to geographically distant deep water assemblages. Notably some of the same forms were found as those in the Mediterranean site and the average concentrations were similar. Thus, the mesopelagic protist assemblages of tintinnid ciliates, phaeogromid cercozoans and amphisolenid dinoflagellates we found in the Mediterranean may be of wide geographic distribution. However we can not exclude the possibility of geographically distant populations being genetically distinct.

Admittedly, some of the forms we encountered have long been known to be widely distributed in deep sea waters. For example Challengeranium diodon, was described as Challengeron diadon by Haeckel (1887) from a deep water sample in the Southwest Pacific. It is known from deep water from Norwegian fjords (Jorgensen 1905) to the North Pacific (Gowing 1993) and the Adriatic Sea (Krsinic \& Krsinic 2012). Likewise, Xystonellopsis aciculifera, was originally described by Jorgensen as Favella aciculifera from deep water net tows in both the Eastern and Western Mediterranean (Jorgensen 1924). It is considered a deep sea species in the Adriatic Sea (Krsinic \& Grbec 2006) and is also known from deep water sampling in the Gulf of Mexico (Balech 1968). Amphisolenia and Triposolenia species, although relatively rare, are also widely distributed in tropical and warm water systems and have been described as "shade species" because they are found usually deep in the water column (Balech 1967). Also we should point out that some of our mesopelagic forms have been reported from shallower waters. For example, Amphisolenia bidentata has been reported in the Bay of Villefranche (Gomez \& Gorsky 2003) at 50 m depth and Triplosolenia bicornta also been reported in shallow $(<30 \mathrm{~m})$ waters of the Eastern Mediterranean (Balkis 2009). Eutintinnus haslae was described from samples taken a variety of depths in the Tropical Pacific and Indian Oceans (Taniguchi \& Hada 1981). Albatrosiella agasszi was found in the South Atlantic in plankton net tows taken between 100 and $10 \mathrm{~m}$ depth (Fernandes 2004).

The general patterns of seasonality we observed in 2017 were repeated in 2018. The tintinnid forms most abundant in the surface layer ('invasive' to deep waters) markedly dominated during the period of water column mixing but were otherwise a minority component of the tintinnid assemblage (Fig. 4). Within the tintinnid assemblage of deep forms, the 2017 pattern of Xystonellopsis spicata appearing during the period of water column mixing while $X$. aciculifera, generally present the rest of the year, declined to undetectable concentrations was repeated in 2018 (Fig. 6). The phaeogromids were nearly absent during the period of water column mixing (Fig. 10). Amphisolenids were dominated by Amphisolenia spp. during the period of water column mixing but otherwise usually dominated by Triposolenia (Fig. 12).

While seasonal patterns were quite similiar in 2017 and 2018, there were some obvious differences in concentrations, at least with regard to tintinnid and oligotrich ciliates. Summary statistics of the protist assemblages, given in Table 1 , show that average concentrations and relative temporal variability, as indicated coefficient of variation of average concentration, of all of the ciliate groups was higher in 2018 than in 2017. In contrast, the summary statistics of 
both the phaeogromids and amphisolonids for 2017 closely resemble those for 2018. Using standard statistical tests (e.g., t-test, correlation analyses of both transformed and raw data) differences between abundances in 2017 and 2018 were not significant nor were there any significant relationships among the groups (data not shown) other than that shown in Fig. 5 between oligotrich abundance and abundance of invasive tintinnids.

Fortuitous sampling allowed us to assess the response of mesopelagic assemblages to a large increase in particulate matter, presumably material washed into the sea from a flash flood type event, in early July 2018 (Fig. 13). Only one assemblage, the phaeogromids, showed an abrupt change in concentration corresponding with a high concentration of particulate matter, abrupt increase in concentration largely due to one species, Challengeria diodon (Fig. 10). As challengerids are thought to feed on organic aggregates, based on contents of food vacuoles (Gowing, 1986; Gowing \& Bentham 1994), perhaps it is not surprising that a challengerid would respond positively to a transient increase in particulate matter. The lack of any apparent response among tintinnid or oligotrich ciliates or amphisolinids leads to the suggestion that they, in contrast to the phaeogromids, may not participate in the transformation of particulate organic matter that rapidly travels through the mesopelagic, in the form of large, $>20 \mu \mathrm{m}$, particles. Thus, their roles in "the biological carbon pump" may differ from that of the phaeogromids. Interestingly, the response time we found of about two weeks for the mesopelagic assemblage to return to pre-flash flood concentrations is quite similar to that known for the microbial communities of coastal lagoons (Pecqueur et al. 2011).

\section{CONCLUSION}

Our study focused on groups of protists that have been largely neglected in recent years. The forms are relatively large, removed during pre-screening employed in most sequence-based studies, and found in relatively low concentrations requiring examination of material from $10^{1}$ to $10^{2}$ liters, which is rarely attempted. However, their distinctive morphologies permit species identification with relative ease. A uniquely intensive sampling over a two year period permitted detection of distinct, species-specific, temporal dynamics. We found seasonal patterns of abundance in some taxa, and in others non-seasonal successional patterns. Some of the peculiar forms we found in the mesopelagic Mediterranean were also found in sample obtained from the North Atlantic supporting the idea that the organisms may be wide spread. Fortuitous sampling around a flash flood type event associated with the appearance of high concentrations of particulate matter showed an apparent reaction restricted to a single species. We conclude that there are a variety of protist taxa endemic to the mesopelagic, that the populations are dynamic, have distinct ecologies, and they may be widely distributed in the deep waters of the world ocean.

\section{ACKNOWLEDGEMENTS}

We thank the skipper, Jean-Yves Carval, and crew members, Pierre Cohen and Julien Garde, of the vessel "Sagitta III" for ship operations and precious aid in sampling. Water column profile data used to calculate MLD and the stratification 
index for Point $\mathrm{C}$ were kindly supplied by the SOMLIT coastal observation program (Service d'Observation en Milieu LITtoral, SOMLIT/ILICO, the French Coastal Monitoring Network). Financial support for this work was provided by the CNRS and the French Agence National de la Recherche through the AncesStram project coordinated by David Moreira, Université Paris-Sud. The value of the questions and comments of both the reviewers and the Associate Editor are gratefully acknowledged. However, the authors retain full responsibility for all errors of fact and interpretation.

\section{LITERATURE CITED}

Agusti, S., González-Gordillo, J. I., Vaqué, D., Estrada, M., Cerezo, M. I., Salazar, G., Gasol, J.M. \& Duarte, C.M. 2015. Ubiquitous healthy diatoms in the deep sea confirm deep carbon injection by the biological pump. Nature Comm., 6: 7608.

Arndt, A., Hausmann, K., \& Wolf, M. 2003. Deep-sea heterotrophic nanoflagellates of the Eastern Mediterranean Sea: qualitative and quantitative aspects of their pelagic and benthic occurrence. Mar. Ecol. Prog. Ser., 256:45-56

Bailey, J.W. 1851. Microscopical examination of soundings made off the coast of the United States by the U.S. Coast Survey. Smithsonian Contrib. Knowledge, Vol. 2, Art. 3, 15 pp. +1 pl.

Bailey, J.W. 1856. Notice of microscopic forms found in the soundings of the Sea of Kamtschatka- with a plate. Amer. J. Sci. Arts, 22:1-6.

Bailey, J.W. 1857. Report upon the results of microscopic examinations of the soundings made by Lieut. Berryman of the U.S. Navy, on his recent voyages to and from Ireland in the Arctic. Amer. J. Sci. Arts, 23:153-157.

Balkis, N. 2009. Seasonal variations of microphytoplankton assemblages and environmental variables in the coastal zone of Bozcaada Island in the Aegean Sea (NE Mediterranean Sea). Aquat. Ecol., 43:249-270.

Behrenfeld, M. J., O’Malley, R. T., Siegel, D. A., McClain, C. R., Sarmiento, J. L., Feldman, G. C., Milligan, A. J., Falkowski, P.G., Boss, E.S. 2006. Climate-driven trends in contemporary ocean productivity. Nature, 444: 752-755.

Boltovskoy, D. 2017. Vertical distribution patterns of Radiolaria Polycystina (Protista) in the World Ocean: living ranges, isothermal submersion and settling shells. J. Plankton Res., 39:330-349.

Boras, J. A., Montserrat Sala, M., Baltar, F., Arístegui, J., Duarte, C. M., \& Vaqué, D. 2010. Effect of viruses and protists on bacteria in eddies of the Canary Current region (subtropical northeast Atlantic). Limnol. Oceanogr., 55:885-898.

Boyd, P.W., Claustre, H., Levy, M., Siegel, D.A., Weber, T. Multi-facted particle pumps drive carbon sequestration in the ocean. Nature, 568:327-335. 
de Boyer Montégut, C., Madec, G., Fischer, A. S., Lazar, A., and Iudicone, D. 2004. Mixed layer depth over the global ocean: An examination of profile data and a profile-based climatology. J. Geophys. Res. Oceans, 109, doi: 10.1029/2004JC002378.

Burd, A. B., Hansell,D. A.,Steinberg, D. K., Anderson, T. R., Arıstegui, J., Baltar, F., Beaupré , S. R., Beusseler, K. O., De Hairs, F., Jackson, G. A., Kadko, D., Koppelmann,R., Lampitt,R. S., Nagata,T., Reinthaler, T., Robinson, C.,Robison, B., Tamburini, C., \& Tanaka,T. 2010. Assessing the apparent imbalance between geochemical and biochemical indicators of meso-and bathypelagic biological activity: what the @\$\#! is wrong with present calculations of carbon budgets? Deep-Sea Res. II, 57:1557-1571.

Celussi, M., Quero, G. M., Zoccarato, L., Franzo, A., Corinaldesi, C., Rastelli, E., Lo Martire, M., Galand, P.E., Ghiglione, J.-F., Chiggiato, J., Coluccelli, A., Russo, A., Pallavinicini, A., Fonda Umani, S., Del Negro P., \& Luna, G.M. 2018. Planktonic prokaryote and protist communities in a submarine canyon system in the Ligurian Sea (NW Mediterranean). Progr. Oceanogr., 168:210-221.

Costello, M. J., \& Breyer, S. 2017. Ocean depths: the mesopelagic and implications for global warming. Curr. Biol., 27: R36-R38.

Countway, P. D., Vigil, P. D., Schnetzer, A., Moorthi, S. D., \& Caron, D. A. 2010. Seasonal analysis of protistan community structure and diversity at the USC Microbial Observatory (San Pedro Channel, North Pacific Ocean). Limnol. Oceanogr., 55:2381-2396.

Chun, C. 1903. Aus den Tiefen des Weltmeeres . Schilderungen von der Deutchen Tieffee-Expedition (2nd Ed.). Gustav Fischer, Jena, pp 592.

Dave, A. C., and Lozier, M. S. 2010. Local stratification control of marine productivity in the subtropical North Pacific. J. Geophys. Res. Oceans, 115, doi: 10.1029/2010JC006507.

Dolan, J. R., Ciobanu, M., Marro, S., \& Coppola, L. 2017. An exploratory study of heterotrophic protists of the mesopelagic Mediterranean Sea. ICES J. Mar. Sci., doi:10.1093/icesjms/fsx218

Duret, M. T., Pachiadaki, M. G., Stewart, F. J., Sarode, N., Christaki, U., Monchy, S., Srivastava, A., \& Edgcomb, V.P. 2015. Size-fractionated diversity of eukaryotic microbial communities in the Eastern Tropical North Pacific oxygen minimum zone. FEMS Microbiol. Ecol., 91, doi: 10.1093/femsec/fiv037

Edgcomb, V.P. 2016. Marine protist associations and environmental impacts across trophic levels in the twilight zone and below. Curr. Opin. Microbiol., 31: 169-175. 
Ehrenberg, C.G. 1844. On microscopic life in the ocean at the South Pole, and at considerable depth. Ann. Mag. Nat. Hist., 14:169-181.

Ehrenberg, C.G. 1854. Charakteristik der neuen mikroskopischen Organismen des tiefen atlantischen Oceans. Ber. Akad. Wiss. Berlin, Jahre 1854, 236-250.

Ehrenberg, C. G. 1858. Über die organischen Lebensformen in unerwartet grossen Tiefen des Mittelmeeres. K. Preuss. Akad. Wiss. Berlin, Monatsberichte, Year 1857, 538-571.

Ehenber C. G. 1861. Über den Tiefgrund des stil-len Oceans zwischen Californien und den Sandwich-Inseln aus bis 15600' Tiefe nach Lieutenant Brooke. K. Preuss. Akad. Wiss. Berlin, Monatsberichte, Year 1860, 819-833.

Fernandes, L. F. 2004. Tintinnids (Ciliophora, Tintinnina) from subtropical waters of the Southern Brazil: II. Families Dictyocystidae, Rhabdonellidae, Tintinnidae and Xystonellidae. Rev. Brasil. Zool., 21:605-628.

Fowler, G.H. (1898). Contributions to our knowledge of the plankton of the Faroe Channel- No. VI. Description of a new mid-water tow net. Discussion of the midwater fauna (mesozooplankton). Notes on Doliolum tritonis and D. nationalis, and on Parathemisto abyssorum. Proc. Zool. Soc. (London), 40:567-585.

Fukuda, H., Sohrin, R., Nagata, T., \& Koike, I. 2007. Size distribution and biomass of nanoflagellates in meso-and bathypelagic layers of the subarctic Pacific. Aquat. Microb. Ecol., 46:203-207.

Gomez, F. 2007. Trends on the distribution of ciliates in the open Pacific Ocean. Acta Oecologica, 32:188-202

Gómez, F., \& Gorsky, G. 2003. Annual microplankton cycles in Villefranche Bay, Ligurian Sea, NW Mediterranean. J. Plankton Res., 25:323-339.

Gowing, M.M. 1986. Trophic biology of phaeodarian radiolarians and flux of living radiolarians in the upper $2000 \mathrm{~m}$ of the North Pacific central gyre. DeepSea Res. Part A, 33:655-674.

Gowing, M. M., \& Bentham, W. N. 1994. Feeding ecology of phaeodarian radiolarians at the VERTEX North Pacific time series site. J. Plankton Res., 16:707719.

Gowing, M. M., Garrison, D. L., Wishner, K. F., \& Gelfman, C. (2003). Mesopelagic microplankton of the Arabian Sea. Deep-Sea Res. I, 50:1205-1234.

Grattepanche, J. D., Santoferrara, L. F., McManus, G. B., \& Katz, L. A. (2016). Unexpected biodiversity of ciliates in marine samples from below the photic zone. Molec. Ecol., 25:3987-4000. 
Haeckel, E. 1887. Report on the Radiolaria collected by HMS Challenger during the years 1873-1876. Report of the Voyage of HMS Challenger, Zoology, 1887, vol. 18, p. i-clxxxviii, 1-1803.

Haeckel, E., 1891. Plankton-Studien. Jen. Zeits. Naturwissen., 25:232-336. (English translation: Report of the U.S. Commissioner of Fish and Fisheries for 1889 to $1891(1893)$ pp. 565-641).

Haecker, V. 1908. Tiefsee-Radiolarien. Wissenschaftliche Ergebnisse Deutschen Tiefsee-Expedition auf dem Dampfer "Valdivia" 1898-1899, Bd 14: 477-706.

Harting, P., 1863. Bijdrage tot de kennis der mikroskopische fauna en flore van de Banda-Zee. Verh. Konin. Akad. Weten.,10:1-34.

Honjo, S., Eglinton, T. I., Taylor, C. D., Ulmer, K. M., Sievert, S. M., Bracher, A., German, C.R., Edgcomb, V., Francois, R., Iglesias-Rodriguez, M.D., Van Mooy, B. \& Repeta, D.J. 2014. Understanding the role of the biological pump in the global carbon cycle: an imperative for ocean science. Oceanography, 27:10-16.

Hu, S. K., Campbell, V., Connell, P., Gellene, A. G., Liu, Z., Terrado, R., \& Caron, D. A. 2016. Protistan diversity and activity inferred from RNA and DNA at a coastal ocean site in the eastern North Pacific. FEMS Microbiol. Ecol., 92: fiw050.

Ikenoue, T., Bjørklund, K. R., Kruglikova, S. B., Onodera, J., Kimoto, K., \& Harada, N. 2015. Flux variations and vertical distributions of siliceous Rhizaria (Radiolaria and Phaeodaria) in the western Arctic Ocean: indices of environmental changes. Biogeosciences, 12:2019-2046, doi:10.5194/bg-12-20192015.

Irigoien, X., Klevjer, T. A., Røstad, A., Martinez, U., Boyra, G., Acuna, J. L., Bode, A., Echevarria, F., Gonzalez-Gordillo, I., Hernandez-Leon, S., Agusti, S., Aknes, D.L., Duarte, C.M., \& Kaartvedt, S. 2014. Large mesopelagic fishes biomass and trophic efficiency in the open ocean. Nature Comm., 5, DOI: 10.1038/ncomms4271

Jensen, S., Bourne, D. G., Hovland, M., \& Colin Murrell, J. 2012. High diversity of microplankton surrounds deep-water coral reef in the Norwegian Sea. FEMS Microbiol. Ecol., 82:75-89.

Jørgensen, E., 1905. The protist plankton and the diatoms in bottom samples. In: O. Nordgaard (Ed.), Hydrographical and biological investigations in Norwegian fiords. Bergens Museum Skrifter 1: 59-151

Jörgensen, E. 1924. Mediterranean Tintinnids. Report on the Danish Oceanographical Expeditions 1908-10 to the Mediterranean and adjacent Seas. 2 J.3. (Biology):1-110

Kim, D. Y., Countway, P. D., Jones, A. C., Schnetzer, A., Yamashita, W., Tung, C., \& Caron, D. A. 2014. Monthly to interannual variability of microbial eukaryote assemblages at four depths in the eastern North Pacific. ISME J., 8:515-530. 
Kimor, B. 2002. Deep-sea plankton exploration in historical perspective. In: Benson, K.R.,\& Rehbock, P.F. (ed) Oceanographic history the Pacific and Beyond. University of Washington Press, Seattle, pp 210-214

Krsinic, F., \& Grbec, B. 2006. Horizontal distribution of tintinnids in the open waters of the South Adriatic (Eastern Mediterranean). Sci. Mar., 70:77-88.

Lo Bianco, S. 1903. "Le pesche abissali eseguite da F. A. Krupp col Yacht Puritan nelle adiacenze di Capri ed in altre località del Mediterraneo." Mittheil. Zool. Stat. Neapel, 16, 109-279.

López-García, P., Rodríguez-Valera, F., Pedrós-Alió, C., \& Moreira, D., 2001. Unexpected diversity of small eukaryotes in deep-sea Antarctic plankton. Nature 409:603-607.

Lozier, M. S., Dave, A. C., Palter, J. B., Gerber, L. M., and Barber, R. T. 2011. On the relationship between stratification and primary productivity in the North Atlantic. Geophys. Res. Lett., 38, doi: 10.1029/2011GL049414.

Marshall, N.B., 1979. Developments in Deep-Sea Biology. Blanford Press, Dorset, U.K., $556 \mathrm{pp}$.

Mills, E. L. (1980). Alexander Agassiz, Carl Chun and the problem of the intermediate fauna. In Sears, M., Merriman, D. (ed) Oceanography: the past, Springer, New York, NY., pp 360-372.

Morgan-Smith, D., Herndl, G. J., Van Aken, H. M., \& Bochdansky, A. B. 2011. Abundance of eukaryotic microbes in the deep subtropical North Atlantic. Aquat. Microb. Ecol., 65:103-115.

Not F., Gausling R., Penn K., Heidelberg J., \& Worden, A. Z. 2007. Vertical distribution of picoeukaryotic diversity in the Sargasso Sea. Environ. Microbiol., 9:1233-1252.

Pachiadaki, M. G., Taylor, C., Oikonomou, A., Yakimov, M. M., Stoeck, T., \& Edgcomb, V. 2016. In situ grazing experiments apply new technology to gain insights into deep-sea microbial food webs. Deep Sea Res. II, 129:223-231.

Pecqueur, D., Vidussi, F., Fouilland, E., Le Floc'h, E., Mas, S., Roques, C., Salles, S., Tournoud,M.-G., Mostajir, B. 2011. Dynamics of microbial planktonic food web components during a river flash flood in a Mediterranean coastal lagoon. Hydrobiologia, 673:13-27.

Pernice, M.C., Forn, I., Gomes, A., Lara, E., Alonso-Saez, L., Arrieta, J.M., del Carmen Garcia, F., Hernando-Morales, V., MacKenzie, R., Mestre, M., Sintes, E., Teira, E., Valencia, J., Varela, M.M., Vaque, D., Duarte, C.M., Gasol, J.M., \& Massana, R. 2015. Global abundance of planktonic heterotrophic protists in the deep ocean. ISME J., 9:782-792. 
Rebotim, A., Voelker, A.H., Jonkers, L., Waniek, J.J., Meggers, H., Schiebel, R., Fraile, I., Schulz, M. \& Kucera, M., 2017. Factors controlling the depth habitat of planktonic foraminifera in the subtropical eastern North Atlantic. Biogeosciences, 14:827-859.

Robinson, C., Steinberg, D.K., Koppelmann, R., Robison, B., Anderson, T.R., Aristegui J., Carlson, C.A., Frost, J.R., Ghiglione, J.-F., Hernandez-Leon, S., Jackson, G., Queguiner, B., Ragueneau, O., Rassoulzadegan, F., Tamburini, C., Tanaka, T., Wishner, K.F., \& Zhang, J., 2010. Mesopelagic zone ecology and biogeochemistrya synthesis. Deep-Sea Res. II, 57:1504-1518.

Rocke, E., Pachiadaki, M.G. , Cobban, A., Kujawinski, E.B., \& Edgcomb V.P. 2015. Protist community grazing in deep ocean waters. PLoS ONE 2015 http://dx.doi.org/10.1371/journal.pone.0124505.

Russell, F.S. 1927. The vertical distribution of plankton in the sea. Biol. Rev., 2:213-262.

Safi, K.A., Robinson, K.V., Hall, J.A., Schwarz, J., \& Maas, E.W. 2012. Ross Sea deepocean and epipelagic microzooplankton during the summer-autumn transition period. Aquat. Microb. Ecol., 67:123-137.

Sohrin, R., Imazawa, M., Fukuda, H., \& Suzuki, Y. 2010. Full-depth profiles of prokaryotes, heterotrophic nanoflagellates, and ciliates along a transect from the equatorial to the subarctic central Pacific Ocean. Deep-Sea Res. Part II, 57:15371550.

St. John, M.A., Borja, A., Chust, G., Heath, M., Grigorov, I., Mariani, P., Martin, A.P., Santos, R.S. 2016. A dark hole in our understanding of marine ecosystems and their services: Perspectives from the mesopelagic community. Front. Mar. Sci., $3: 31$.

Taniguchi, A., \& Hada, Y. 1981. Eutintinnus haslae n. sp., a new ciliated protozoa from the Tropical Pacific and Indian Oceans. La Mer, 19:18-22.

Tanaka, T., Rassoulzadegan, F. 2002. Full-depth profile (0-2000 m) of bacteria, heterotrophic nanoflagellates and ciliates in the NW Mediterranean Sea: vertical partitioning of microbial trophic structures. Deep-Sea Res. II, 49:2093-2107.

Terrado, R., Vincent, W. F., \& Lovejoy, C. 2009. Mesopelagic protists: diversity and succession in a coastal Arctic ecosystem. Aquat. Microb. Ecol., 56:25-39.

Weiner, A., Aurahs, R., Kurasawa, A., Kitazato, H., Kucera, M., 2012. Vertical niche partitioning between cryptic sibling species of a cosmopolitan marine planktonic protist. Mol. Ecol. 21: 4063-4073. 
Xu, D., Li, R., Hu, C., Sun, P., Jiao, N., \& Warren, A. 2017. Microbial eukaryote diversity and activity in the water column of the South China Sea based on DNA and RNA high throughput sequencing. Front. Microbiol., 8:1121.

Yamaguchi, A., Watanabe, Y., Ishida, H., Harimoto, T., Furusawa, K., Suzuki, S., Ishizaka, J., Ikeda, T., Mac Takahashi, M. 2002. Structure and size distribution of plankton communities down to the greater depths in the western North Pacific Ocean. Deep Sea Res. II, 49:5513-5529.

Yamaguchi, A., Watanabe, Y., Ishida, H., Harimoto, T., Furusawa, K., Suzuki, S., Ishizaka, J., Ikeda, T., \& Mac Takahashi, M. 2004. Latitudinal differences in the planktonic biomass and community structure down to the greater depths in the western North Pacific. J. Oceanogr., 60:773-787.

Zhao, F., Filker, S., Xu, K., Huang, P., \& Zheng, S. 2017. Patterns and drivers of vertical distribution of the ciliate community from the surface to the abyssopelagic zone in the Western Pacific Ocean. Front. Microbiol., 8:2559.

Zoccarato, L., Pallavicini, A., Cerino, F., Fonda Umani, S., \& Celussi, M., 2016. Water mass dynamics shape Ross Sea protist communities in mesopelagic and bathypelagic layers. Prog. Oceanogr., 149:16-26.

SUPPORTING MATERIAL

1. Supplementary Figures (2) with legends.

2. Supplementary Excel Data File 
JEM ms Supplementary Figures (2) with Legends
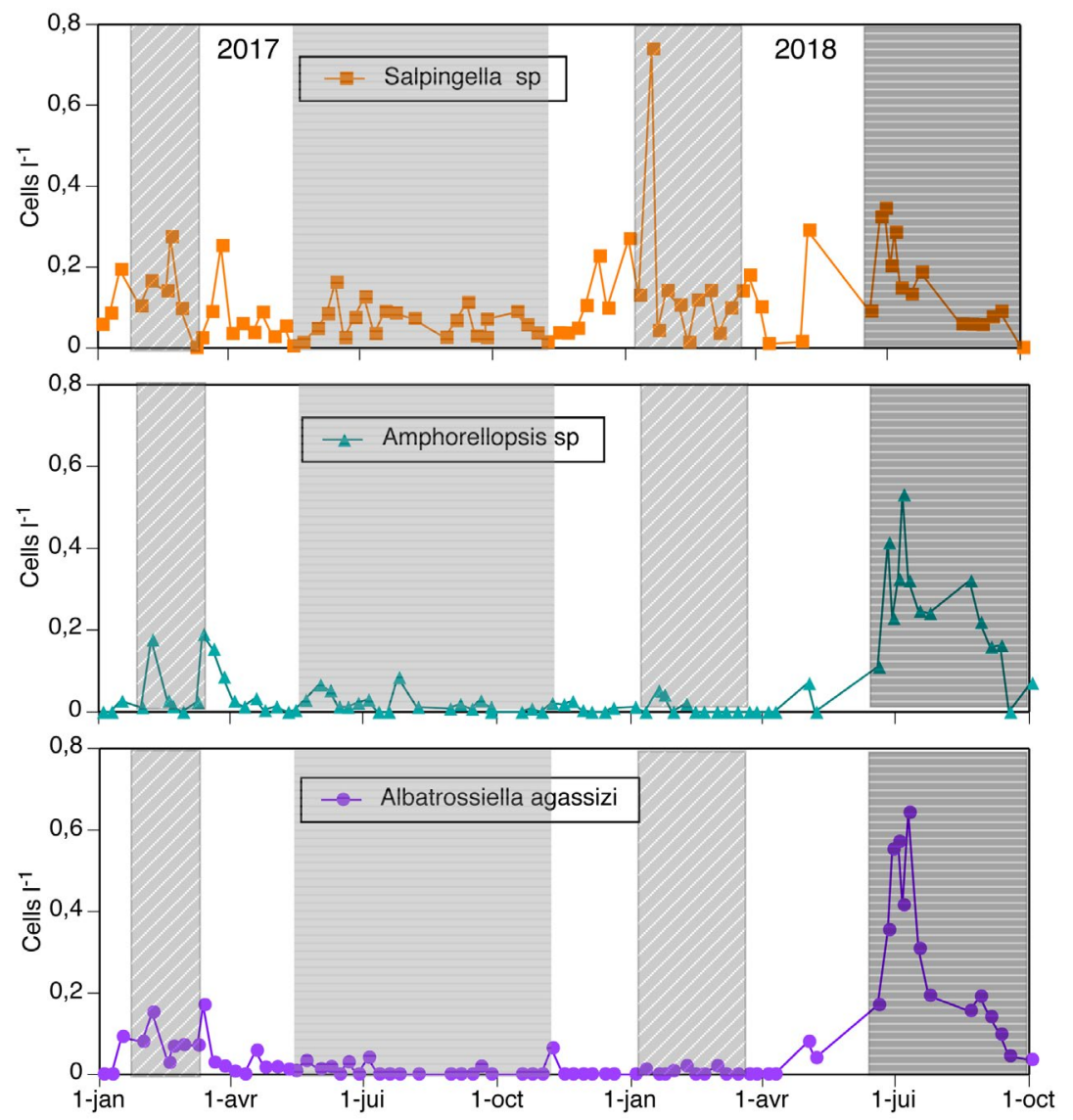

Supplemental Figure 1. Temporal variability in the concentrations of the 3 most commonly found deep sea tintinnids. All three are characterized by small lorica opening diameters (10 - $25 \mu \mathrm{m}$ diam.) suggestive of a diet of small nano and large pico-sized prey: Salpingella sp. (Fig. 1 A.), the 'ringed' Amphorellopsis sp. (Fig. 1 E) and Albatrossiella agassizi (Fig. 1.G.). Note that the three co-varied in the later 6 months of 2018.

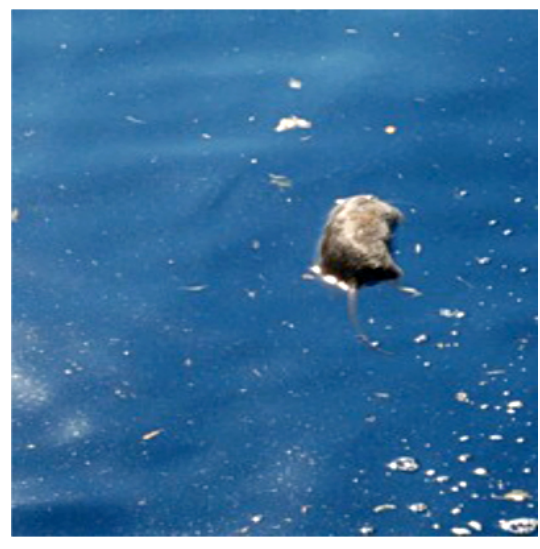

Supplemental Figure 2. Photo of sea surface at sampling site, approximately 1 Km offshore, on the morning of July 62018 following the flash flood type rain event during the evening of July 5, 2019. 
Note

Your are perhaps viewing a PDF file.

This Supplementary Data File is an Excel File.

to be available for readers to easily manipulate the data.

Unfortunately, some publishers

transform everything into a PDF!

The original Excel file is available on request (dolan@obs-vlfr.fr) 
Taxon

\section{Tintinnid Ciliates}

Albtrossiella agassizi

Amphorellopsis sp 'small sac'

Amphorellopsis "ringy sp."

Brandtiella "new sp."

Daturella striata

Eutintinnus haslae

Eutintinnus sp. "tiny trumpet $\varnothing 15 "$

Eutintinnus sp. " tiny tube $\varnothing 9 "$

Xystonellopsis aciculifera

Ormosella sp. "small stemless"

Parundella lohmannii

Parundella longa

Parundella messinensis

Salpingella sp. "thin $s p "$

Xystonellopsis spicata

Xystonellopsis scyphium

Acanthostomella conicoides

Amphorides laackmanni

Amphorellopsis tetragona

Amphorellopsis tropica

Amphorellopsis turbinea

Amphorides quadrilineata

Ascampbelliella torulata

Canthariella pyramidata

Climacocylis scalaria

Codonaria cistelllula

Codonella amphorella

Codonella elongata

Codonella nationalis

Codonellopsis lusitanica

Condonellopsis morchella

Codonellopsis orthoceras

Condonellopsis pusilla

Cyttarocylis ampulla

Dadayiella ganymedes

Dadayiella pachytoecus

Dictyocysta elegans

Dictyocysta entzi

Dictyocysta lepida

Dictyocysta mitra

Epiplocylis undella

Eutintinnus apertus
Dec Jan Jar Ja Jan30: Fe Fe FeFe M M Mì Mi Ał Ał Ar Ap M Mć

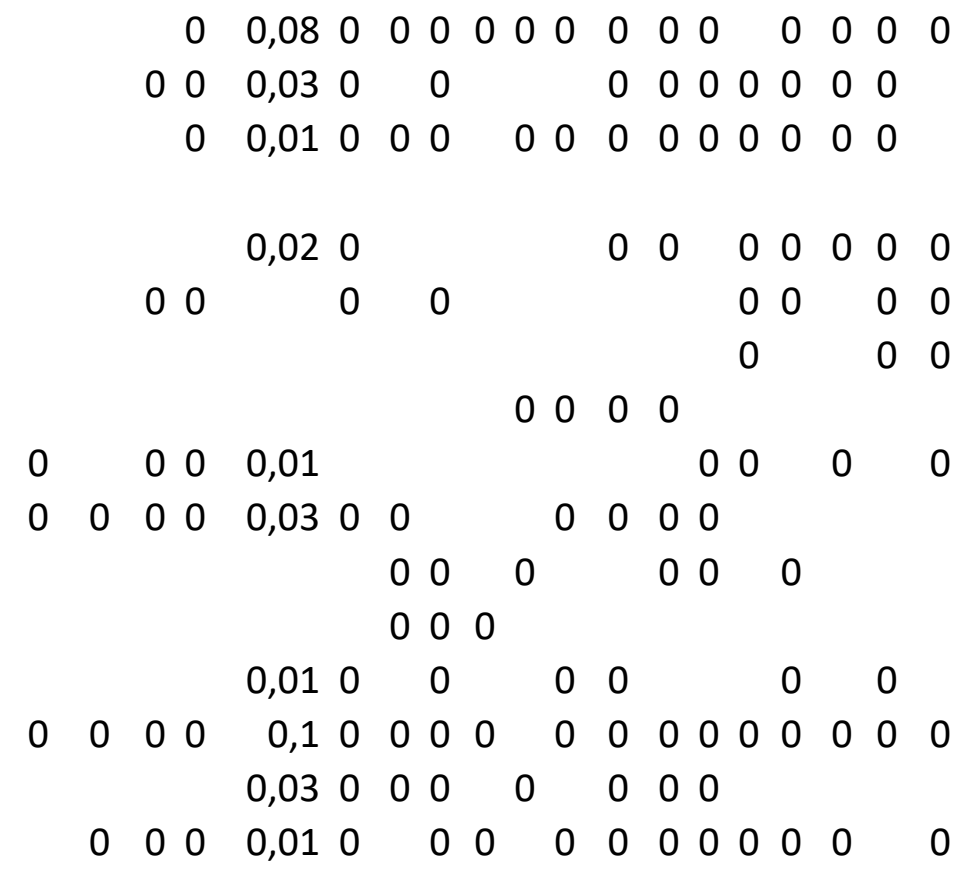
$\begin{array}{llllllllllllll}0 & 0 & 0,15 & 0 & 0 & 0 & 0 & 0 & 0 & 0 & 0 & 0 & 0 & \end{array}$
$0 \quad 0,01$

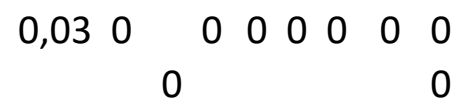
0

0

$\begin{array}{lll}0,01 & 0 & 0 \\ & 0\end{array}$

$\begin{array}{llll}0 & 0 & 0 & 0\end{array}$

$0 \quad 0$

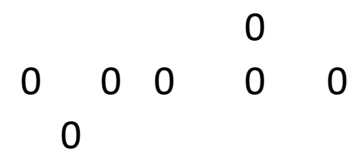

$\begin{array}{llllllllllllllll}0 & 0 & 0,03 & 0 & 0 & 0 & 1 & 0 & 0 & 1 & 0 & 0 & 0 & 0 & 0\end{array}$

$\begin{array}{llll}0 & 0 & 0 & 0\end{array}$

$0 \quad 0$

0

$\begin{array}{lll}0 & 0 & 0\end{array}$

$\begin{array}{llll}0 & 0 & 0 & 0\end{array}$

0 
Eutintinnus fraknoii

Eutintinnus lusus-undae

0,01

Eutintinnus perminutus

Eutintinnus pinguis

Eutintinnus stramentus

Eutintinnus tubulosus

Odontophorella serrulata

Ormosella apsteini

Ormosella bresslaui

Ormosella trachelium

Parundella aculeata

Proplectella fastigata

Protorhabdonella curta

Rhabdonella spiralis

Salpingella acuminata

Salpingella curta

Salpingella decurtata

Salpingella faurei

Salpingella liminata

Salpingella rotundata

Steenstrupiella steenstrupii

Stenosomella nivalis

Stenosomella ventricosa

Tintinnidium sp. " $\varnothing 50 "$

Tintinnopsis angulata

Tintinnopsis beroidea

Tintinnopsis baltica

Tintinnopsis campanula

Tintinnopsis cylindrica

Tintinnopsis minuta

Tintinnopsis nana

Tintinnopsis radix

Undella clevei

0

0

$\begin{array}{lll}0 & 0,01 & 0\end{array}$
$0 \quad 0$
0

Undella hyalina

Undella sp. "tiny $\varnothing 1 " 1$

Undellopsis marsupialis

Xystonella lanceolata

Xystonella treforti

$\begin{array}{lll}0 & 0\end{array}$

$0 \begin{array}{lllllllllllllll}0 & 0,02 & 0 & 0 & 0 & 0 & 0 & 0 & 2 & 0 & 0 & 0 & 0 & 0 & 0\end{array}$

$0,01 \quad 00 \quad 0$

0

Xystonellopsis paradoxa

\section{Oligotrich Ciliates}

$30 \mu \mathrm{m}$ Oligotrich

$40 \mu \mathrm{m}$ Oligotrich

$\begin{array}{lllllllllllllllll}0 & 0 & 0 & 0,22 & 0 & 1 & 1 & 1 & 0 & 0 & 0 & 0 & 0 & 0 & 0 & 0 & 0\end{array}$

$\begin{array}{lllllllllllllllll}0 & 1 & 0 & 0,57 & 0 & 1 & 1 & 1 & 0 & 0 & 0 & 0 & 0 & 0 & 0 & 0 & 0\end{array}$

$50 \mu \mathrm{m}$ Oligotrich 
$40 \mu \mathrm{m}$ Tontonid oligotrich

$70 \mu \mathrm{m}$ Tontonid oligotrich

Laboea strobila

\section{Amphisolenid Dinoflagellates}

Triposolenia bicornis

Amphisolenia bidentata

Amphisolenia extensa

Amphisolenia globifera

Amphisol brevicaudata

Amphisolenia truncata

Amphisolenia sp.

\section{Phaeogromids}

Medusetta sp

Medusetta parthenopaea

Lirella bullata

Challengeron channeri

Challengeranium diadon

Challengeron willemoesii

Challengeria xiphodon

Protocystis tritonis

Euphysetta lucani

Euphysetta pusilla

Liters equiv. examined $=>$

Dates $=>$

0

$\begin{array}{lll}0 & 0 & 0,01\end{array}$

00

0

937082 \# 87,2 \# \# \# \# \# \# \# \# \# \# \#\#\# \#

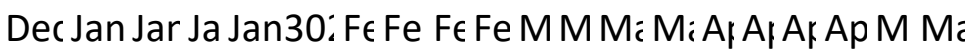

Red denotes deep water taxa

absent or rare in surface water samples 
Mi M Ju Ju Ju Ju Jur Jul Ju Ju Ju Au Au Se Se Se Se Or O، Or Or Novi Nor No Nc De Dec Der Jal Jan1 Jar Ja Jar

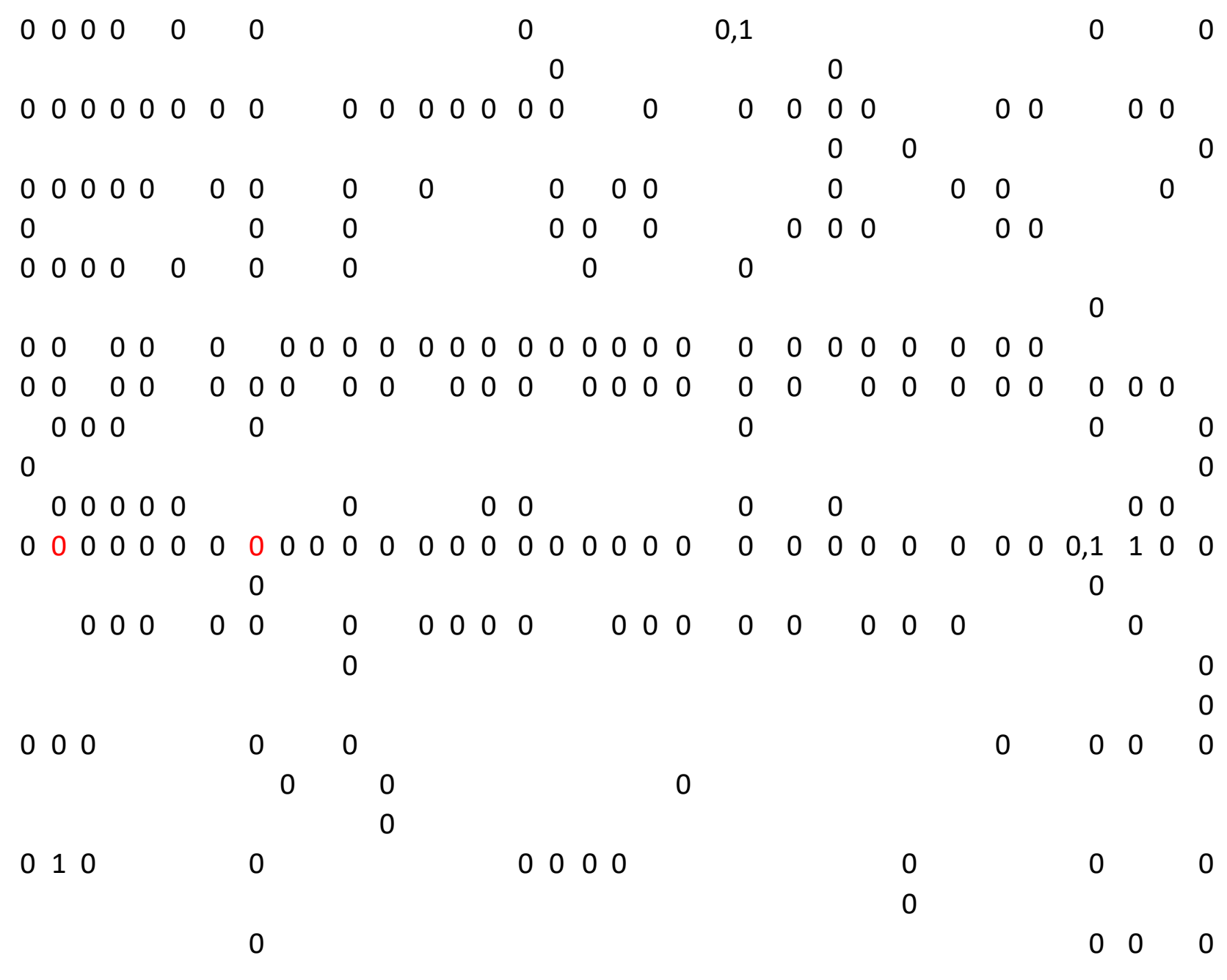

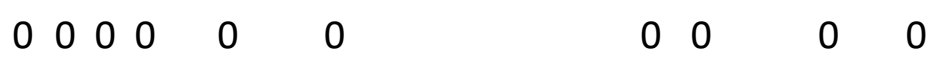

0

0

0

$0 \quad 0$

0

0

0

$\begin{array}{llll}1 & 0 & 0 & 4\end{array}$

000

$\begin{array}{lllll}0 & 0 & 0 & 0 & 0\end{array}$

0

0 
0

0

0

0

0

0

$\begin{array}{lll}0 & 0 & 0\end{array}$

$\begin{array}{lll}0 & 0 & 0\end{array}$

0

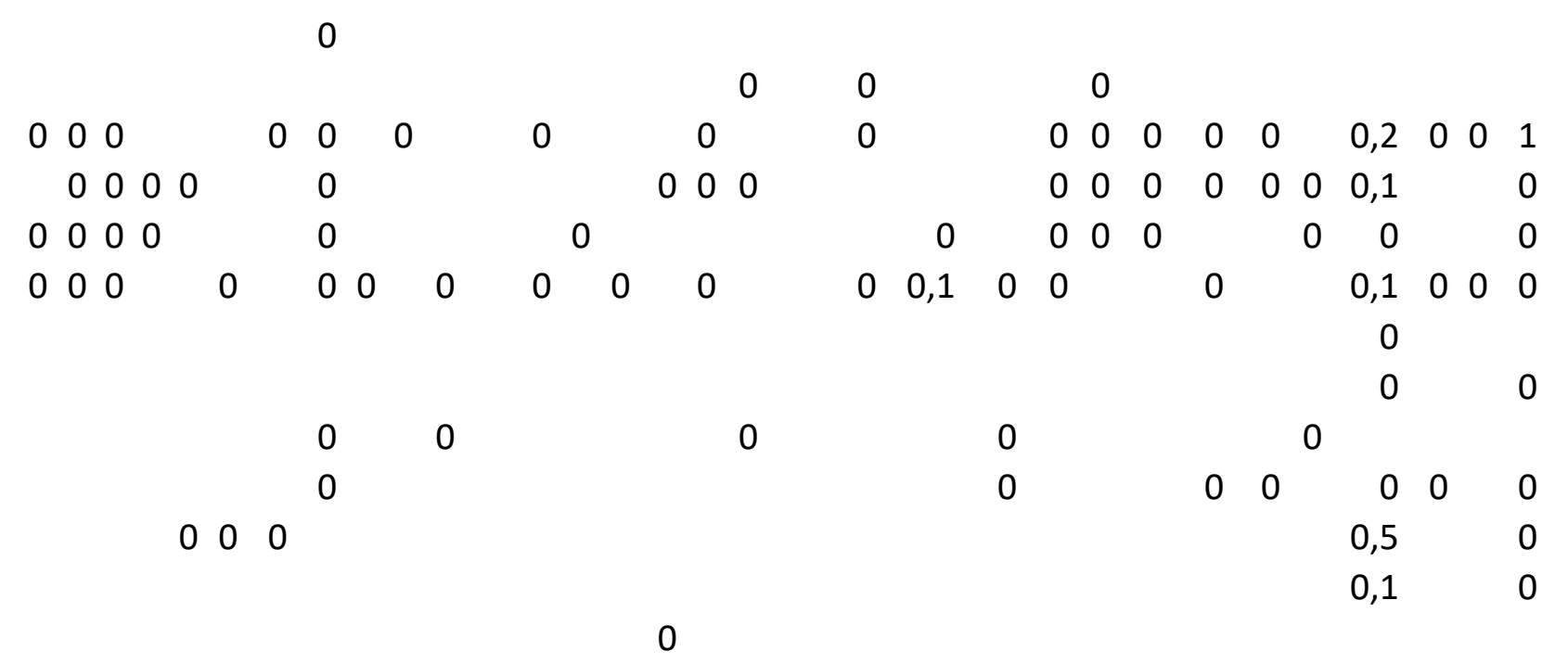

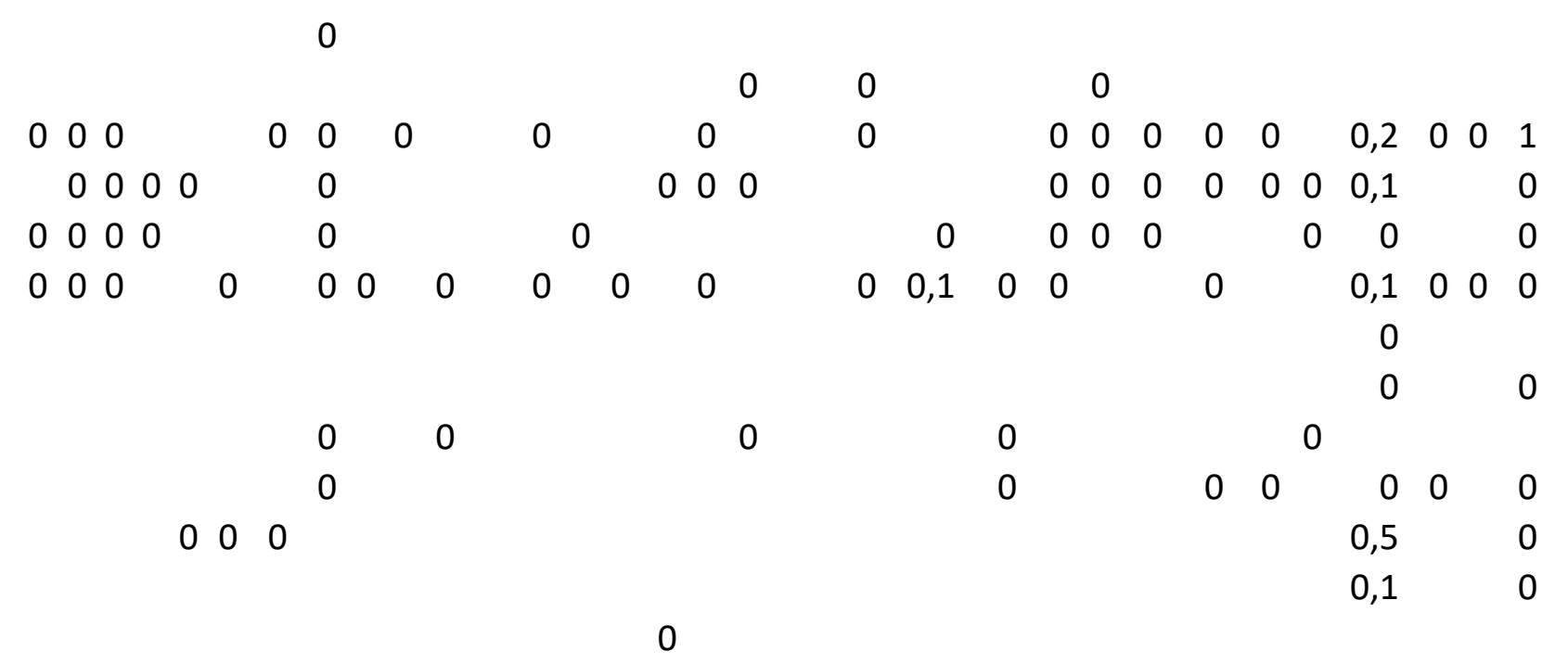

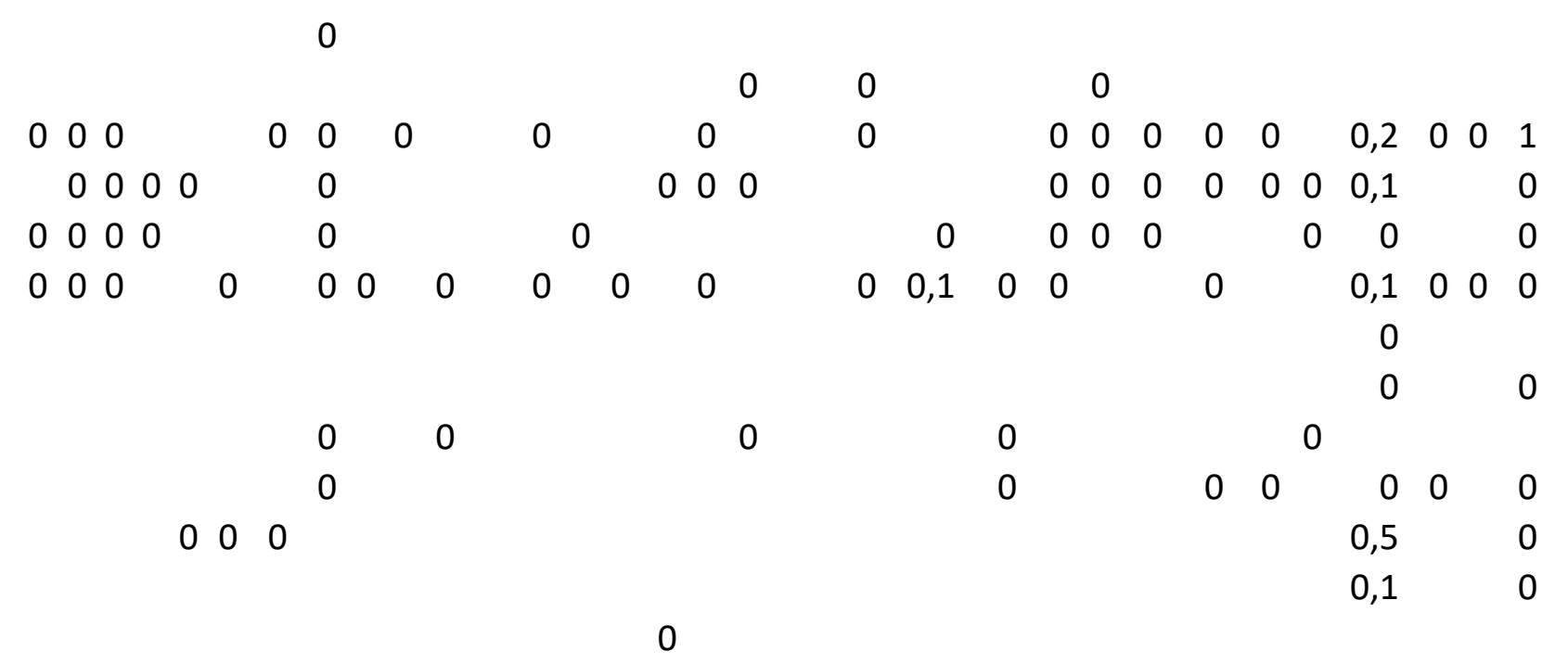

$0^{0} 0^{0}$

00

0

0

00

0

$\begin{array}{llll}0 & 0 & 0 & 0\end{array}$

0

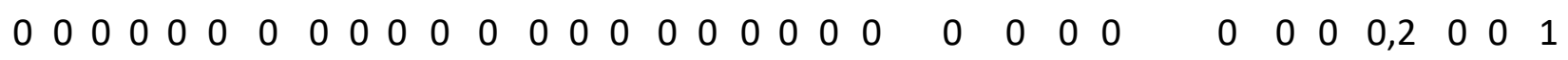
$\begin{array}{lllllllllllllllllllllllllllllllll}0 & 0 & 0 & 0 & 0 & 0 & 0 & 0 & 0 & 0 & 0 & 0 & 0 & 0 & 0 & 0 & 0 & 0 & 0 & 0 & 0 & 0,2 & 0 & 0 & 0 & 0 & 0 & 0 & 0 & 0,4 & 1 & 0 & 1\end{array}$ $0 \begin{array}{llllllllllllllllllllllllllllll}0 & 0 & 0 & 0 & 0 & 0 & 0 & 0 & 0 & 0 & 0 & 0 & 0 & 0 & 0 & 0 & 0 & 0 & 0,1 & 0 & 0 & 0 & 0 & 0 & 0 & 0 & 0,2 & 1 & 0 & 0\end{array}$ 
$\begin{array}{llll}0 & 0 & 0 & 0\end{array}$

0

0

0

0

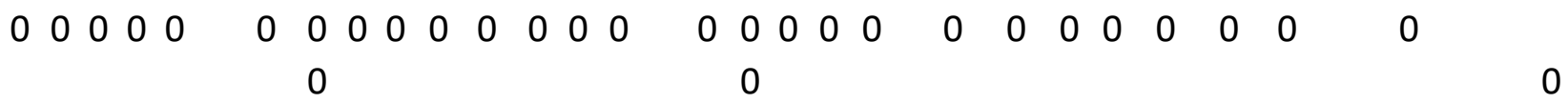
$\begin{array}{llllll}0 & 0 & 0 & 0 & 0 & 0\end{array}$

$\begin{array}{llllllllllllllllllllllllllll}0 & 0 & 0 & 0 & 0 & 0 & 0 & 0 & 0 & 0 & 0 & 0 & 0 & 0 & 0 & 0 & 0 & 0 & 0 & 0 & 0 & 0 & 0 & 0 & 0 & 0 & 0\end{array}$ $\begin{array}{llll}0 & 0 & 0\end{array}$

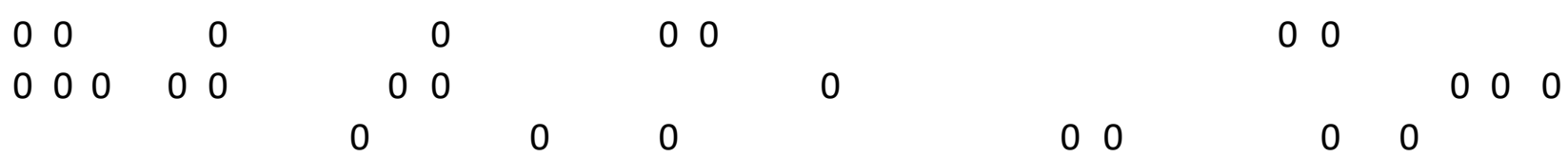
$\begin{array}{llllllllllllllllllllllllllllll}0 & 0 & 0 & 0 & 0 & 0 & 0 & 0 & 0 & 0 & 0 & 0 & 0 & 0 & 0 & 0 & 0 & 0 & 0 & 0 & 0 & 0 & 0 & 0 & 0 & & 0 & 0 & 0 & 0\end{array}$

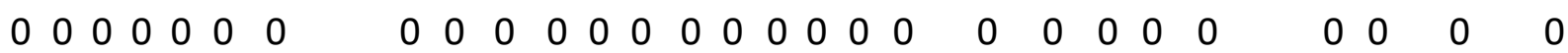
$\begin{array}{llllllllllllllllllll}0 & 0 & 0 & 0 & 0 & 0 & 0 & 0 & 0 & 0 & 0 & 0 & 0 & 0 & 0 & 0 & 0 & 0 & 0 & 0\end{array}$ $\begin{array}{lllllllllll}0 & 0 & 0 & 0 & 0 & 0 & 0 & 0 & 0 & 0 & 0\end{array}$

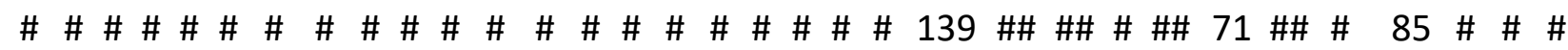
Mi M Ju Ju Ju Ju Jur Jul Ju Ju Ju Au Au Se Se Se Se Or O، Or Or Nov` Noı No Nc De Dec Der Jal Jan1 Jar Ja Jar 


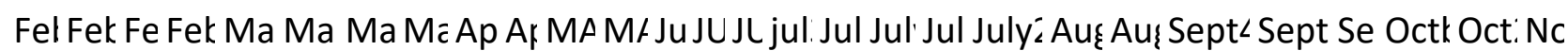

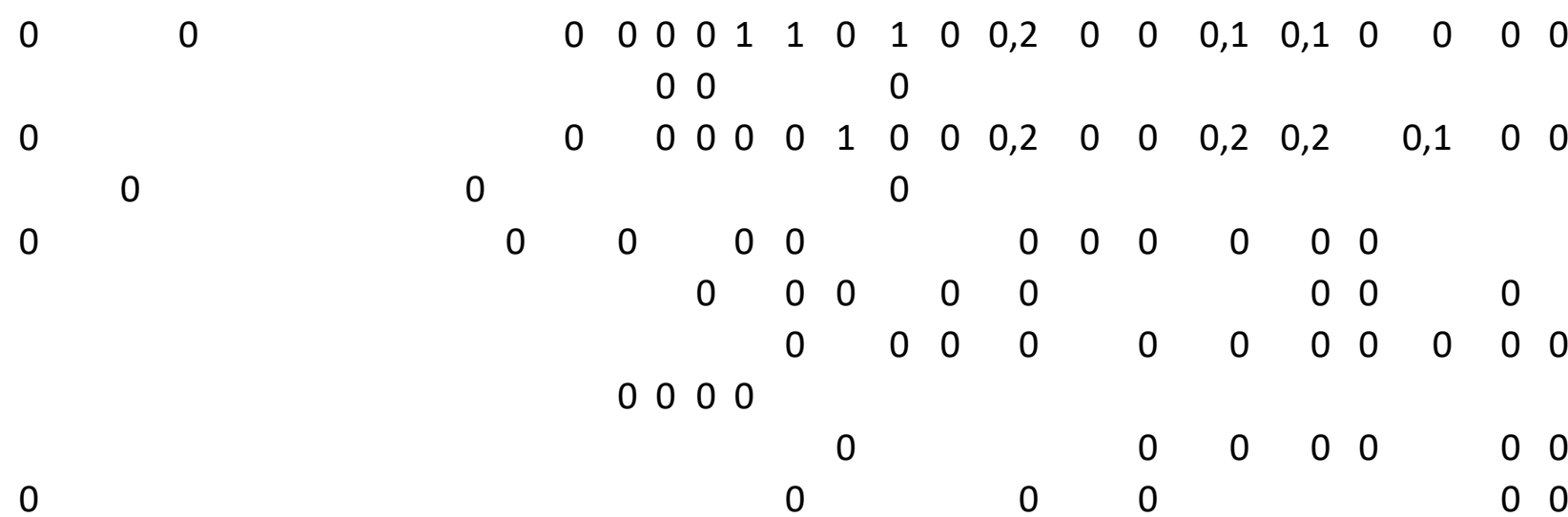
0 $\begin{array}{llllllllllll}0 & 0 & 0 & 0 & 0 & 0 & 0 & 0 & 0 & 0 & 0 & 0\end{array}$

$\begin{array}{lllllllllllllll}0 & 0 & 0 & 0 & 0 & 0 & 0 & 0 & 0 & 0 & 0 & 0 & 0 & 0 & 0\end{array}$ $\begin{array}{llllllllllllllllllllllllllll}0 & 0 & 0 & 0 & 0 & 0 & 0 & 0 & 0 & 0 & 0 & 0 & 0 & 0 & 0 & 0 & 0 & 0 & 0 & 0,2 & 0 & 0 & 0,1 & 0,1 & 0 & & 0 & 0\end{array}$ $\begin{array}{llllllll}0 & 0 & 0 & 0 & 0 & 0\end{array}$ $\begin{array}{lllll}0 & 0 & 0 & 0 & 0\end{array}$ 0

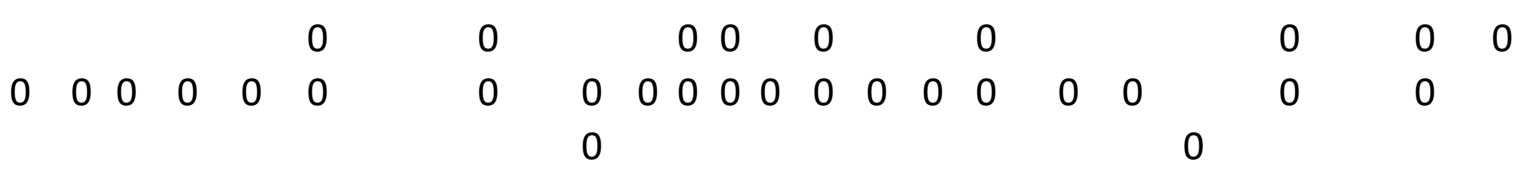
$\begin{array}{llllllllllllll}0 & 0 & 6 & 2 & 1 & 0 & 1 & 0 & 1 & 0 & 0 & 0 & 0\end{array}$ $\begin{array}{llllllllll}0 & 0 & 0 & 0 & 0 & 0 & 0 & 0 & 0 & 0\end{array}$ $\begin{array}{rrrrrrrrr} & 0 & 0 & 0 & & & & \\ 0 & & 0 & 0 & 0 & & 0 & \\ 0 & & 0 & 0 & 0 & 0 & & 0 & \\ 0 & 0 & 0 & 0 & 0 & & 0 & 0 & 0 \\ & 0 & 0 & 0 & & & & \end{array}$

$\begin{array}{llllllllll} & 0 & 0 & 0 & 0 & 0 & 0 & 0 & 0 & 0\end{array}$
$\begin{array}{rrrrrrrrrrrrrrr}0 & 2 & 5 & 26 & 7 & 15 & 4 & 1 & 1 & 1 & 0 & & 0 & 0 & 0 \\ 0 & 0 & 0 & 0 & 0 & 0 & 0 & 0 & 0 & & & 0 & & \end{array}$ $\begin{array}{llllllll}0 & & 0 & 0 & 0 & & & \\ 0 & & & & 0 & 0 & 0\end{array}$ $\begin{array}{lllllll}0 & 0 & 0 & 0 & 0 & 0 & 0\end{array}$ $\begin{array}{llllllllll}0 & 0 & 5 & 2 & 1 & 0 & 0 & 1 & 0\end{array}$ $0 \quad 0 \quad 0$ 
0

0

$0 \quad 0$

$\begin{array}{lllll}0 & 0 & 0 & 0 & 0\end{array}$

00

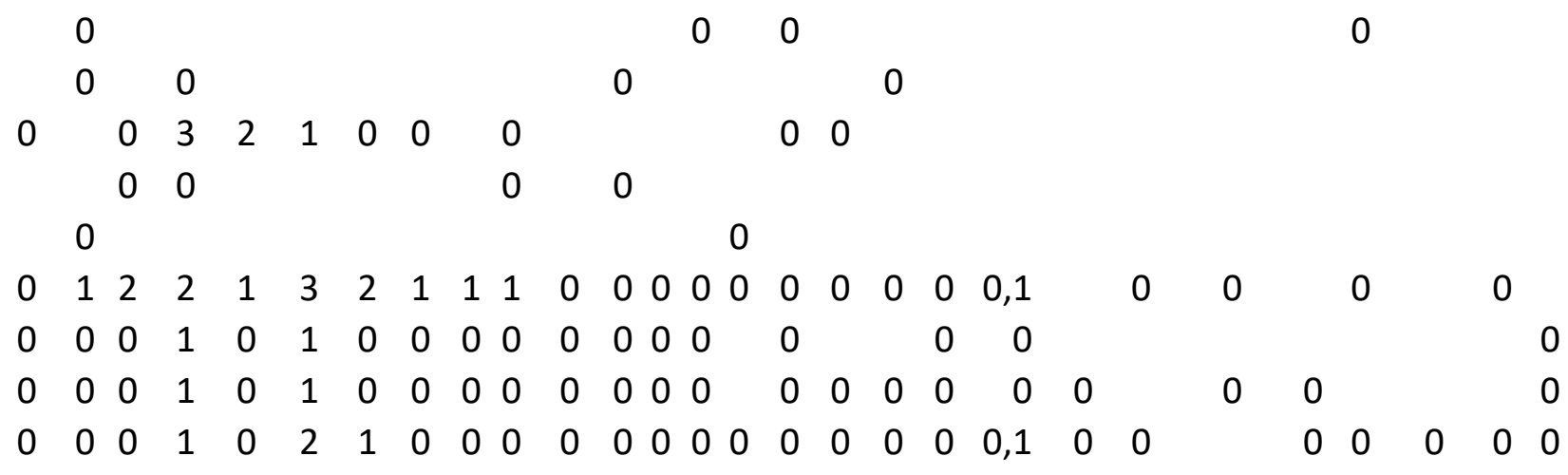

$\begin{array}{rrrrrrrrrrrrrrrrrrrrrr} & 0 & 0 & 0 & 0 & 0 & & & & & & & 0 & 0 & 0 & & & 0 & \\ 0 & 2 & 0 & 6 & 0 & 1 & 4 & 0 & 0 & 0 & 0 & 0 & 0 & 0 & 0 & & & 0 & 0 & \\ 0 & 0 & 1 & 0 & 0 & 0 & & & 0 & & & & & & 0 & & & & 0\end{array}$

$\begin{array}{llllllll}0 & 0 & 0 & 0 & 0 & 0 & 0 & 0\end{array}$

$\begin{array}{lll}0 & 0 & 0\end{array}$

$0 \quad 0$

0

0

$\begin{array}{lllll}0 & 0 & 0 & 0 & 0\end{array}$

$\begin{array}{llll}0 & 0 & 0\end{array}$

$\begin{array}{lllllll}0 & 0 & 0 & 0 & 0 & 0 & 0\end{array}$

0

0

$\begin{array}{llll}0 & 0 & 0 & 0\end{array}$

$\begin{array}{llllllllllllllllllllllllllll}1 & 0 & 1 & 1 & 1 & 1 & 0 & 0 & 0 & 1 & 0 & 0 & 0 & 0 & 0 & 0 & 0 & 0 & 0 & 0,1 & 0 & 0 & 0 & 0 & 0 & 0,1 & 0 & 0\end{array}$ $\begin{array}{llllllllllllllllllllllllllll}0 & 0 & 0 & 1 & 1 & 1 & 1 & 0 & 1 & 1 & 0 & 0 & 0 & 0 & 0 & 0 & 0 & 0 & 0 & 0,1 & 0 & 0 & 0,1 & 0,2 & 0 & 0,2 & 0 & 0\end{array}$ $\begin{array}{llllllllllllllllllllllllllll}0 & 0 & 0 & 1 & 1 & 0 & 0 & 0 & 0 & 0 & 0 & 0 & 0 & 0 & 0 & 0 & 0 & 0 & 0 & 0,1 & 0 & 0 & 0 & 0 & 0 & 0 & 0 & 0\end{array}$ 


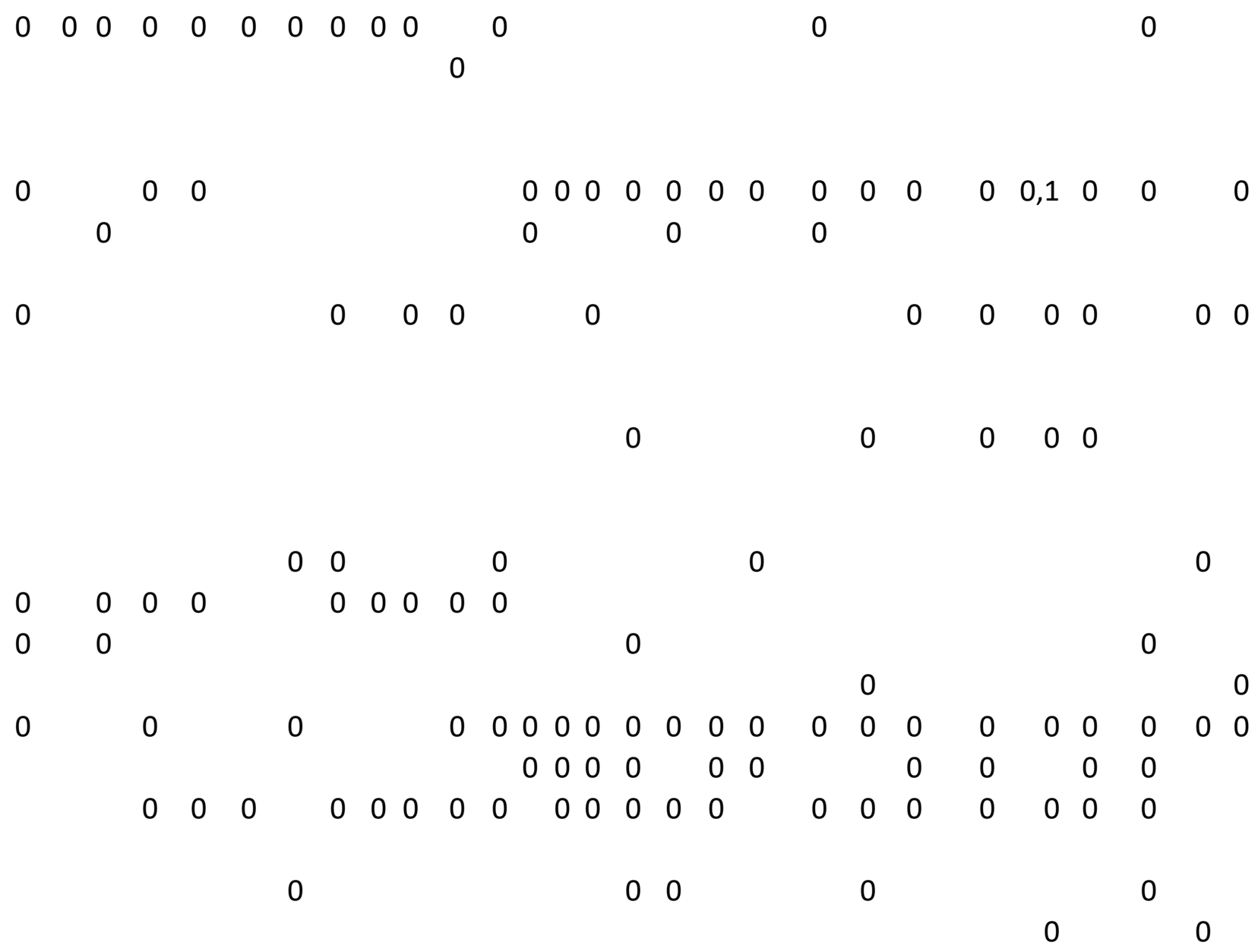

8577 \# 42 \#\# 617273 \# \# 98 \#\# \# \# \# \# \# \#\# \# 166 \#\# \#\# 10792 \# 113 \#\# \#

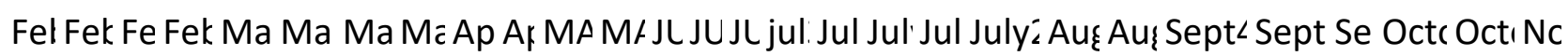




\section{Tintinnid Ciliates}

$0 \quad 0 \quad 0$ Albtrossiella agassizi

$0 \quad 0$ Amphorellopsis sp 'small sac' 19

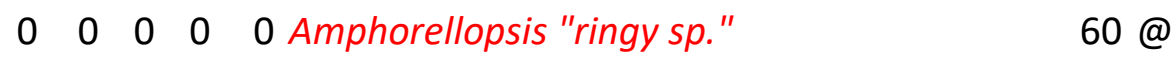
Brandtiella "new sp." 6

$0 \quad$ Daturella striata 37

$\begin{array}{lllll}0 & 0 & 0 & 0 & \text { Eutintinnus haslae }\end{array}$

0000 Eutintinnus sp. "tiny trumpet $\varnothing 15 "$

Eutintinnus sp. "tiny tube $\varnothing 9 "$

$\begin{array}{llllllll}0 & 0 & 0 & 0 & 0 & \text { Xystonellopsis aciculifera } & 46 @ 0\end{array}$

000 Ormosella sp. "small stemless" $46 @$

0 Parundella lohmannii 26

Parundella longa 6

Parundella messinensis $\quad 34$

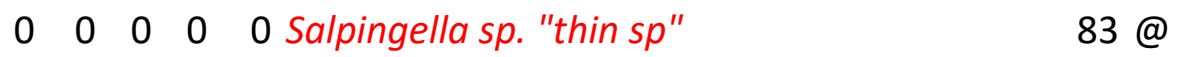

Xystonellopsis spicata 16

$0 \quad 0 \quad$ Xystonellopsis scyphium $41 @$

Acanthostomella conicoides

Amphorides laackmanni

Amphorellopsis tetragona

Amphorellopsis tropica

Amphorellopsis turbinea

$0 \quad$ Amphorides quadrilineata

Ascampbelliella torulata

Canthariella pyramidata

Climacocylis scalaria

Codonaria cistelllula

Codonella amphorella

Codonella elongata

Codonella nationalis

Codonellopsis lusitanica

0 Condonellopsis morchella

Codonellopsis orthoceras

0 Condonellopsis pusilla

Cyttarocylis ampulla

Dadayiella ganymedes

Dadayiella pachytoecus

Dictyocysta elegans

Dictyocysta entzi

0 Dictyocysta lepida

o 0 o Dictyocysta mitra

o Epiplocylis undella

Eutintinnus apertus 


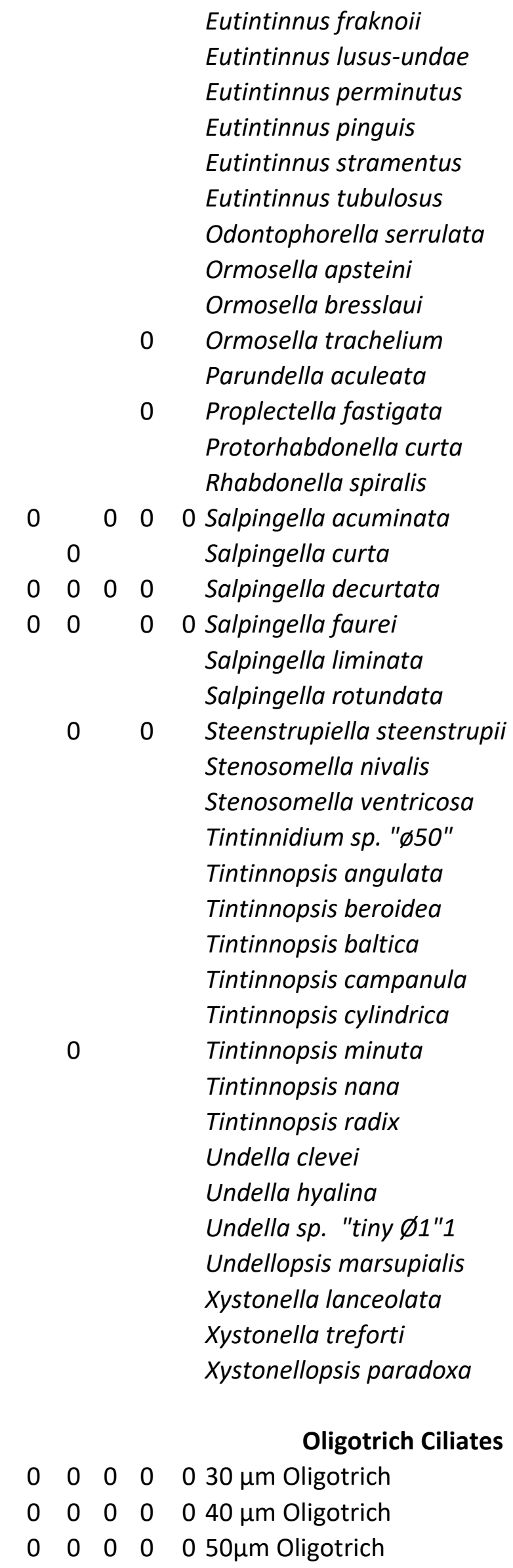


$40 \mu \mathrm{m}$ Tontonid oligotrich

$70 \mu \mathrm{m}$ Tontonid oligotrich

Laboea strobila

\section{Amphisolenid Dinoflagellates}

$\begin{array}{llll}0 & 0 & \text { Triposolenia bicornis } & 56\end{array}$

$0 \quad 0$ Amphisolenia bidentata 13

0 Amphisolenia extensa 7

00 Amphisolenia globifera 54

Amphisol brevicaudata 3

Amphisolenia truncata 1

Amphisolenia sp. 5

\section{Phaeogromids}

Medusetta sp 18

Medusetta parthenopaea $\quad 31$

0 Lirella bullata 12

Challengeron channeri 2

000 Challengeron diadon 65

$0 \quad$ Challengeron willemoesii 45

000 Protocystis xiphodon 56

Protocystis tritonis 3

Euphysetta lucani $\quad 18$

$\begin{array}{lll}0 & \text { Euphysetta pusilla } & 14\end{array}$

668758 \#\# 83 <= Liters equiv. examined

Nor No' No De Dec<= Dates 


\section{Tintinnid Ciliates}

Brandtiella sp. "new sp"

$3 \quad 0,034562212$

Parundella difficillus

20,023041475

Proplectella subcaudata

Salpingella acuminata

Salpingella sp. "thin sp"

$22 \quad 0,253456221$

Xystonella acus

Xystonella treforti

\section{Oligotrichs}

$40 \mu \mathrm{m}$ Oligotrich

$1 \quad 0,011520737$

Phaeogromids

Challengeria xiphodon

$2 \quad 0,023041475$

Euphysetta pussila

$1 \quad 0,011520737$

Lirella bullata

Medusetta sp

\section{Amphisolenid Dinoflagellates}

Amphisolenia astragulus

$1 \quad 0,011520737$

Amphisolenia bidentata

$5 \quad 0,057603687$

Amphisolenia globulosa

$6 \quad 0,069124424$

Amphisolenia lacintata

$5 \quad 0,057603687$

Amphisolenia sp

Triplosolenia bicornis

$3 \quad 0,034562212$

\section{Sample 1 DATA}

$100 \mathrm{l}=>60 \mathrm{ml}$

site depth $=1060 \mathrm{~m}$

Meteor event \# M150_423

Septem18_2018

$36^{\circ} 53,935 \mathrm{~N}$

$25^{\circ} 7,185 \mathrm{~W}$

Total vol ex $=52 \mathrm{ml}$

Vol eq $=86.8 \mathrm{~L}$

\section{Sample 2 DATA}

$120 \mathrm{~L}=>80 \mathrm{ml}$

site depth $=439 \mathrm{~m}$

Meteor event \# M150_308

Septem12_2018

$38^{\circ} 48,35 \mathrm{~N}$ 
$27^{\circ} 3,063 \mathrm{~W}$

Total Vol Ex $=64 \mathrm{ml}$

Vol Eq Ex $=96 \mathrm{~L}$

Red denotes deep water taxa

absent or rare in surface water samples

in time-series data from NW Medit.

Sample 1 tins/I

Sample 2 tins/L

Sample 1 Phaeos/I

Sample 2 Phaeos/I

Sample 1 Amphis/I

Sample 2 Amphis/L
0,311059908

0,083333333

0,034562212

0,114583333

0,230414747

0,041666667
0,197196621

0,074572773

0,136040707 
Sample 2 raw count Sample 2 cells/L

$\begin{array}{ll}2 & 0,020833333 \\ 1 & 0,010416667 \\ 1 & 0,010416667 \\ 2 & 0,020833333 \\ 1 & 0,010416667 \\ 1 & 0,010416667\end{array}$

$5 \quad 0,052083333$

10,010416667

$5 \quad 0,052083333$

$\begin{array}{rr}3 & 0,03125 \\ 1 & 0,010416667\end{array}$ 